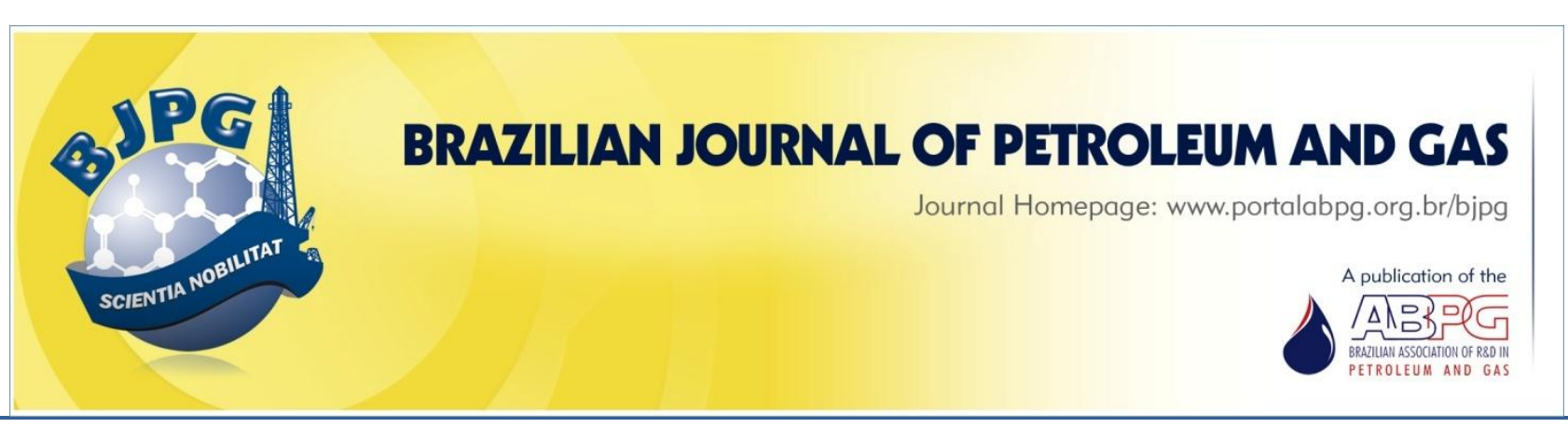

\title{
ADSORPTION OF CRUDE OIL IN AQUEOUS ENVIRONMENT USING WILD CANE FIBER: EQUILIBRIUM AND KINETIC STUDIES
}

\author{
${ }^{a}$ Franca, P. M.; ${ }^{a}$ Santos, A. P.; ${ }^{a}$ Queiroz, C. G.; ${ }^{a}$ Santos, K. K. A.; ${ }^{\text {a }}$ Silva, A. C. M.; ${ }^{a}$ Mattedi, S. ${ }^{1}$ \\ ${ }^{\mathrm{a}}$ Federal University of Bahia, Graduate Program in Chemical Engineering, Salvador-BA, Brazil
}

Received: 29.08.2019 / Revised: 29.10.2019 / Accepted: 03.11.2019 / Published on line: 20.12.2019

\begin{abstract}
This work evaluates the adsorption capacity of the wild cane fiber (Gynerium Sagittatum) in crude oil. Both untreated biomass and treated with ionic liquid [2HEA][Ac] and acetylated were studied for oil spill cleanup in aqueous environment. Crude oil adsorption tests were performed in a thermostatic bath, varying the time for the kinetic study and the amount of oil for isotherm model. Kinetic study of oil adsorption allowed us to identify that the untreated fiber reached saturation in 90 minutes, while the fiber treated with acetylated and ionic liquid reached saturation in 30 minutes. In equilibrium, the total amount of oil adsorbed by the untreated fiber was $3.8 \mathrm{~g}$, whereas in acetylated and ionic liquid treated fiber, the obtained maximum adsorption capacity was 4.4 and $3.7 \mathrm{~g}$, respectively. The remediation process using wild cane fiber followed a second order kinetic rate and Sips and Toth isotherm models provided the best fit to experimental data.
\end{abstract}

\section{KEYWORDS}

crude oil; adsorption; wild cane (Gynerium Sagittatum)

\footnotetext{
${ }^{1}$ To whom all correspondence should be addressed.

Address Federal University of Bahia, Graduate Program in Chemical Engineering, Rua Professor Aristídes Novis 2, Federação Escola Politécnica da UFBA $-2^{\circ}$ andar, Salvador, Bahia, Brazil.

ZIP Code: 40210-630 | Phone number: +55 7132839810 | e-mail: silvana@ufba.br

doi:10.5419/bjpg2019-0028
} 


\section{INTRODUCTION}

One of the major ecological concerns, nowadays, is the environmental impact caused by activities associated with oil. Areas located close to facilities that transport, produce, and distribute oil are at a greater risk. Contamination caused by consumption of petroleum products, such as fuel oils used in vessels, corresponds to the largest portion of oil introduced into the sea due to human activities. Generally, this type of contamination occurs slowly and chronically (Abdelwahab, 2014; Azzam \& Madkour, 2008; Chen et al., 2018; Cortez et al., 2018; Costa et al., 2018; Doshi et al., 2018; Elkady et al., 2015; Silva \& Gomes, 2012; Viju et al., 2019; Wei et al., 2003).

To mitigate the effects of oil spills, several separation processes have been set in place, including mechanical, physical, chemical, and biological processes. Among the separation processes, sorption techniques have been studied to remove petroleum from environmental accidents and industrial effluents.

In these separation processes, various types of materials, such as natural or synthetic ones, are applied. To be considered good sorbents, such materials must have oleophilic and hydrophobic properties, attracting the oil preferentially to water (Cao et al., 2017; Cortez et al., 2018; Costa et al., 2018; Deschamps et al., 2003; Sueiro et al., 2011; Tamis et al., 2011; Viju et al., 2019; Wahi et al., 2013).

Among these separation processes, the treatment to remove oil in aqueous systems using natural fibers stands out due to its low cost and high sorption capacity. Moreover, if a sustainable process is desired, natural fibers are biodegradable materials that can be used at an industrial scale (Costa et al., 2018; Nwadiogbu et al., 2016; Santos et al., 2007).

Current studies report low cost adsorbents to remove contaminants in aqueous effluents: sugar cane (Almeida et al., 2019; Gorgulho et al., 2018; Oliveira et al., 2018; Paula et al., 2017), chitosan (Vidal \& Moraes, 2019), crab biochar (Cai et al., 2019), Phragmites australis (El Shahawy \& Heika, 2018), nettle fiber (Viju et al., 2019), coconut fiber and lasani sawdust (Daniel et al., 2019), banana peel (El-Din et al., 2018), and palm fiber (Abdelwahab et al., 2017).
The wild cane (Gynerium Sagittatum) belongs to Poaceae family and can be found throughout Brazil throughout the year. This fiber is widely used in handicraft production by the residents of Ilha de Maré, Bahia, Brazil (MMA, 2011).

The lack of research using wild cane fiber and the possibility of adding value to a residue in remediating oil spills in aqueous environments were the main motivational factors for this adsorption study. Thus, in this work we investigate the oil sorption capacity of wild cane fiber.

\section{MATERIALS AND METHODS}

\subsection{Material preparation}

Wild cane fiber was donated by craft community of Praia Grande, located in Ilha de Maré (Bahia, Brazil). Initially, the fiber size was reduced in a knife mill and sieved to obtain a homogenous particle size (i.e $1 \mathrm{~mm}$ ) to increase the contact surface and the efficiency of adsorption. Then, it was washed thoroughly with distilled water to remove impurities and placed in an oven at $60^{\circ} \mathrm{C}$ for $24 \mathrm{~h}$ to remove all the water content present in the biosorbent (Abdelwahab et al., 2017; Miranda et al., 2015).

\subsection{Chemical treatments}

The fibers were treated in two different ways: traditional treatment and ionic liquid treatment. For the traditional treatment, two steps were carried out: mercerization and acetylation. In the mercerization treatment, the fibers were treated with a $0.0075(\mathrm{w} / \mathrm{w}) \mathrm{NaOH}$ aqueous solution for 1 hour under agitation of $300 \mathrm{rpm}$. Then, the wild cane was filtered and washed with distilled water until a neutralized $\mathrm{pH}$ be achived (Abdelwahab et al., 2017; Miranda et al., 2015). The acetylation was carried out on the wild cane fiber previously mercerized with a solution $(500 \mathrm{~mL})$ containing a ratio of 1.5:1.0 (w/w) of acetic anhydride, glacial acetic acid, and 20 drops of sulfuric acid, used as a catalyst (Abdelwahab et al., 2017; Miranda et al., 2015). The reaction occurred at $80^{\circ} \mathrm{C}$ under constant stirring for 3 hours. In the ionic liquid treatment, the untreated wild cane was immersed in a $0.75 \mathrm{w} / \mathrm{w}$ aqueous solution of a protic ionic liquid, 2-hydroxyethanolamine acetate ([2HEA] [Ac]). The experiment used a proportion of $0.05 \mathrm{~g}$ of 
fibers per gram of solution (Achinivu et al., 2014; Costa et al., 2018; Hou et al., 2013; Rocha et al., 2017; Rocha et al., 2014). The ionic liquid was synthesized for this task, using the same methodology used previously (Costa et al., 2018; Pin et al., 2019). The treatment was carried out at $80^{\circ} \mathrm{C}$ under constant stirring for 2 hours (Costa et al., 2018; Pin et al., 2019). After both treatments and after mercerization, as mentioned before, the fibers were then washed with distilled water until the $\mathrm{pH}$ was neutralized. Following, they were allowed to dry in an oven at $60^{\circ} \mathrm{C}$ for about 24 hours until the fiber mass remained constant.

\subsection{Biomass characterizations}

\subsubsection{Scanning Electron Microscopy (SEM)}

Scanning Electron Microscopy (SEM) analysis was performed to evaluate the surface morphology of untreated wild cane fiber and after treatments. The analysis was performed on a Tescan equipment, VEGA 3 LMU. The sample was metallized with gold in a Q150R quorum. Variable increases were recorded for untreated and chemically treated fibers.

\subsubsection{Fourier Transform Infrared Spectroscopy (FTIR)}

The use of infrared spectroscopy is a tool that allows the investigation of functional groups and the identification of a specific material, whether organic or inorganic. It is an accessory widely used for the characterization of lignocellulosic fibers.

Fourier transform infrared (FTIR) spectra were recorded using a Shimadzu, IRAffinity-1 spectrometer with a $0.5 \mathrm{~cm}^{-1}$ detector of resolution. Samples were prepared by mixing the material with $\mathrm{KBr}$.

\subsubsection{Thermogravimetric Analysis (TGA)}

Thermogravimetry is the technique that allows, under controlled programming, the investigation of the change in weight of a sample as a function of temperature. The thermogravimetric (TGA) and its derivative (DTA) analysis evaluated the thermal stability of untreated wild cane fibers, acetylated and treated with [2HEA][Ac]. The analysis were performed using a Shimadzu thermocouple, TGA50 , under a nitrogen atmosphere, in a temperature range of 20 to $1000^{\circ} \mathrm{C}$, using a heating rate of $10^{\circ} \mathrm{C}$ $\min ^{-1}$.

\subsubsection{X-Ray Diffraction (XRD)}

The X-ray diffraction method allows one to explore the crystalline structure of materials and provides information about the crystalline fraction of the sample (amorphous, semi-crystalline, and crystalline). The XRD analyses were performed on Shimazdu XRD -7000 to observe the alteration in crystalline behavior through the different types of treatment. Fibers $\mathrm{x}$-ray diffractograms were used for comparison of crystallinity. The crystallinity index was calculated using Equation 1, proposed by the empirical method of Segal et al. (1959).

$$
\text { Cristallinity }(\%)=\left(\left[\frac{I_{002}-I_{A M}}{I_{002}}\right] \times 100\right)
$$

Where:

$\mathrm{I}_{002}=$ diffraction peak intensities for crystalline $(2 \theta \approx$ $\left.22^{\circ}\right)$

$\mathrm{I}_{\mathrm{AM}}=$ diffraction peak intensities for amorphous $(2 \theta$ $\approx 18^{\circ}$ )

\subsubsection{Composition analysis}

The method proposed by Van Soest for determination of fiber chemical composition is based on fractions separation of chemical constituents by detergents. The neutral detergent allows the separation of the soluble fraction (cellular content), formed by proteins, soluble carbohydrates and fats of the cellular wall, of insoluble fraction in the neutral detergent, which is called neutral detergent fiber (NDF), composed by cellulose, hemicellulose, lignin, heat-damaged protein, and ash (Geron et al., 2014).

Thus, for investigation of chemical composition, the Van Soest method was used to determine the percentage of cellulose, hemicellulose, and lignin of wild cane both untreated and after chemical treatment.

\subsection{Crude oil characterization}

The crude oil used in adsorption tests came from Rio Grande do Norte, Brazil, and the analysis were carried out at the Petroleum and Gas Laboratory, located in Salvador, Bahia, Brazil. The physicochemical properties evaluated were density, API, viscosity, and pour point. 
Table 1. List of kinect models.

\begin{tabular}{lc}
\hline \multicolumn{1}{c}{ Cinetic model } & Equation \\
\hline Pseudo-first order & $\frac{d_{q t}}{d t}=k_{1}\left(q_{e}-q_{t}\right)$ \\
Pseudo-second order & $\frac{d_{q t}}{d t}=k_{2}\left(q_{e}-q_{t}\right)^{2}$ \\
Intraparticle diffusion & $q_{t}=k_{i} t^{1 / 2}+C$ \\
\hline
\end{tabular}

The density of oil and its API were measured with an Anton Paar DMA-4500 digital densimeter with uncertainty of $0.00001 \mathrm{~g} / \mathrm{cm}^{3}$, following ASTM D-5002 (2018) and ISO-12185 standards. The viscosity was determined with a Brookfield DVIII Ultra rheometer with uncertainty of $4.7 \mathrm{cp}$, following the ASTM D-445 standard (2018). Analyses were performed at $26^{\circ} \mathrm{C}$, temperature used in kinetic and equilibrium studies.

The petroleum pour point, the Automatic Cloud \& Pour Point Tester HCP 852, was used with uncertainty of $3^{\circ} \mathrm{C}$, following the ASTM D97 standard (2017).

\subsection{Adsorption kinetics}

Kinetic tests were performed in duplicate to define the average time for complete oil saturation, obtaining a kinetic curve that allows the modeling of the experimental data.

The experimental procedure was performed by varying the time and using fixed amounts of fiber and water/oil solution. A portion $(0.5 \mathrm{~g})$ of untreated wild cane, acetylated and treated with [2HEA] [Ac] in $80 \mathrm{ml}$ of solution (approximately $74.8 \mathrm{~g}$ of distilled water and $4.5 \mathrm{~g}$ of oil) were used. The fibers were conditioned in non-woven fabric containment barriers made in dimensions $(8 \mathrm{~cm} \times 2$ $\mathrm{cm} \times 2 \mathrm{~cm}$ ). The experiments were run in a Dubnoff Q226M1 bath from Quimis at $26^{\circ} \mathrm{C}\left( \pm 1^{\circ} \mathrm{C}\right)$ and agitation of $126 \mathrm{rpm}$. The fibers were removed at pre-set times $(5 ; 10 ; 20 ; 30 ; 60 ; 90 ; 120$ minutes), oven-dried at $60^{\circ} \mathrm{C}$ for 24 hours and then weighed. The fiber adsorption capacity was calculated from Equation 2.

$S=\left(\left[\frac{S_{t}-S_{o}}{S_{o}}\right] x 100\right)$
Where:

$\mathrm{S}=$ sorption capacity of the fiber (g adsorbate $/ \mathrm{g}$ adsorbent)

$\mathrm{S}_{\mathrm{t}}=$ total mass after sorption $(\mathrm{g})$

$\mathrm{S}_{0}=$ initial mass $(\mathrm{g})$

Table 1 shows the models that were used to fit the experimental data obtained in the tests: pseudo-first order, pseudo-second order, and intraparticle diffusion (Ho \& Mckay, 1999). The symbols of the models can be described as follows: $\mathrm{q}_{\mathrm{e}} \mathrm{q}_{\mathrm{t}}$ are the adsorbed amounts per gram of adsorbent $\left(\mathrm{mg} . \mathrm{g}^{-1}\right), \mathrm{k}_{1}$ and $\mathrm{k}_{2}$ are the adsorption rate constants, $K_{i}$ is the intraparticle diffusion constant, and $C$ is the value of line intersection with the axis $q_{t}\left(m g \cdot g^{-1}\right)$.

\subsection{Sorption isotherms}

Sorption equilibrium study was carried to evaluate, through the sorption isotherms, the equilibrium relation between the amount of adsorbed oil per unit mass of wild cane fiber and the equilibrium solution concentration (Dotto et al., 2011). Three adsorbents were evaluated: untreated wild cane fiber; acetylated wild cane fiber; and wild cane fiber treated with [2HEA] [Ac]. A portion $(0.5 \mathrm{~g})$ of adsorbent was placed in contact with varied amounts of oil $(2 ; 4 ; 6 ; 8 ; 10 ; 12 ; 14 ; 16$ $\mathrm{mL}$ ) and supplemented with distilled water until 80 $\mathrm{mL}$ (measurements were made on a mass basis through an analytical balance of Shimadzu AX200). The experiments were carried out in a Dubnoff Q226M1 bath from Quimis at $26^{\circ} \mathrm{C}\left( \pm 1^{\circ} \mathrm{C}\right)$ under agitation of $126 \mathrm{rpm}$ in the time obtained according to the best adsorption results in kinetic study. After the period determined by the kinetics, the adsorbent was collected and weighed after 24h. The adsorption capacity of the fiber was calculated from Equation 3. 
Table 2. List of equilibrium isotherms models.

\begin{tabular}{cc}
\hline Isotherm model & Nonlinear form equation \\
\hline Langmuir & $q=\frac{q_{\max } K_{L} C_{e}}{1+K_{L} C_{e}}$ \\
Freundlich & $q_{e}=K_{F} C_{e}^{1 / n}$ \\
Toth & $q_{e}=\frac{q_{m} b p}{\left(1+(b p)^{t}\right)^{1 / t}}$ \\
Sips & $q_{e}=\frac{q_{\max } b C_{e}^{1 / n}}{1+b C_{e}^{1 / n}}$ \\
\end{tabular}

$q=\frac{\left(C_{o}-C_{e}\right) V}{m}$

Where:

$q=$ adsorption capacity $(g / g)$

$\mathrm{C}_{\mathrm{o}}=$ initial concentration of the adsorbate $\left(\mathrm{g} \cdot \mathrm{mL}^{-1}\right)$

$\mathrm{C}_{\mathrm{e}}=$ concentration of adsorbate at equilibrium (g. $\mathrm{mL}^{-1}$ )

$\mathrm{V}=$ volume of the solution $(\mathrm{mL})$

$\mathrm{m}=$ mass of the adsorbent $(\mathrm{g})$

Table 2 shows the isotherms models that were applied to fit the experimental data on the values of $q$ versus Ce: Langmuir, Freundlich, Toth, and Sips (Baghya et al., 2015; Dotto et al., 2011; Nethaji et al., 2013; Foo \& Hameed, 2010). The symbols of the models can be described as follows: $q$ e $q_{e}$ is the adsorbed amount per gram of adsorbent $\left(\mathrm{mg}^{-1} \mathrm{~g}^{-1}\right.$ ), $\mathrm{q}_{\max }$ is the maximum adsorption capacity $\left(\mathrm{mg} \cdot \mathrm{g}^{-1}\right)$, $\mathrm{K}_{\mathrm{L}}$ is the interaction constant adsorbate / adsorbent $\left(\mathrm{L}_{\mathrm{mg}} \mathrm{m}^{-1}\right), \mathrm{C}_{\mathrm{e}}$ is the adsorbate concentration at equilibrium (mg. $\mathrm{L}^{-1}$ ), $1 / \mathrm{n}$ is the constant related to surface heterogeneity, $K_{F}$ is the Freundlich adsorption capacity constant $\left(\mathrm{mg}^{1-(1 / \mathrm{n})} \cdot \mathrm{g}^{-1} \cdot \mathrm{L}^{1 / \mathrm{n}}\right)$, b is the constant of the Toth isotherm $\left(\mathrm{kPa}^{-1}\right), \mathrm{t}$ represents the parameter indicating heterogeneity, b is the Sips constant for adsorbate / adsorbent interaction $\left(\mathrm{mmol}^{-1} \mathrm{~g}^{-1}\right.$.

\section{RESULTS E DISCUSSION}

\subsection{Scanning Electron Microscopy (SEM)}

Through Scanning Electron Microscopy (SEM) it was possible to evaluate changes in fiber morphology caused by chemical treatments, allowing analyzing treatment efficiency.

Figure 1 shows untreated wild cane fiber, where an irregular layer is observed. The irregular layer found is probably related to components such as parenchyma, extractive, wax, and other fatty residues (Jesus et al., 2015).

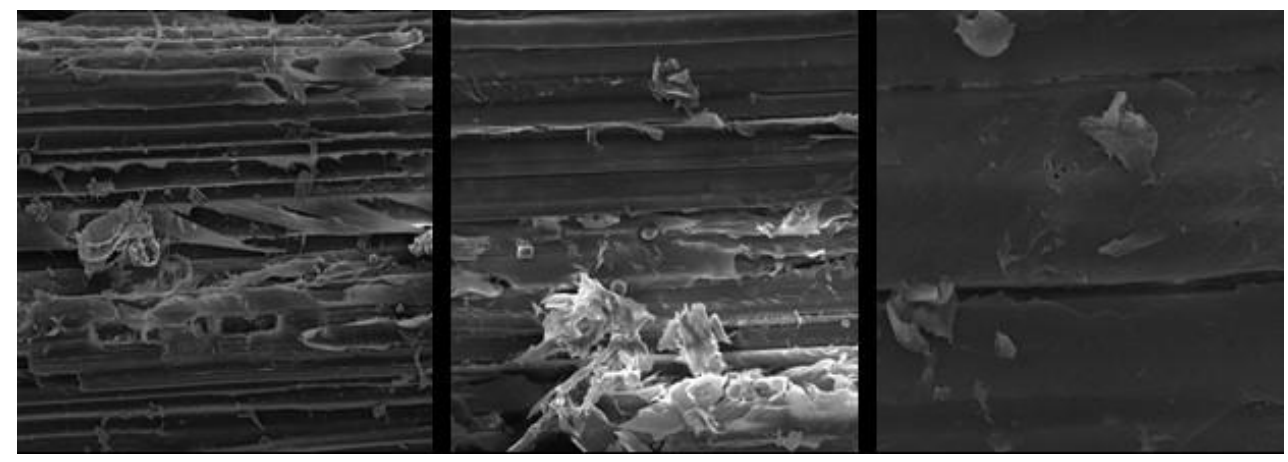

Figure 1. Untreated wild cane with 500x magnification; 1000x and 5000x, respectively. 


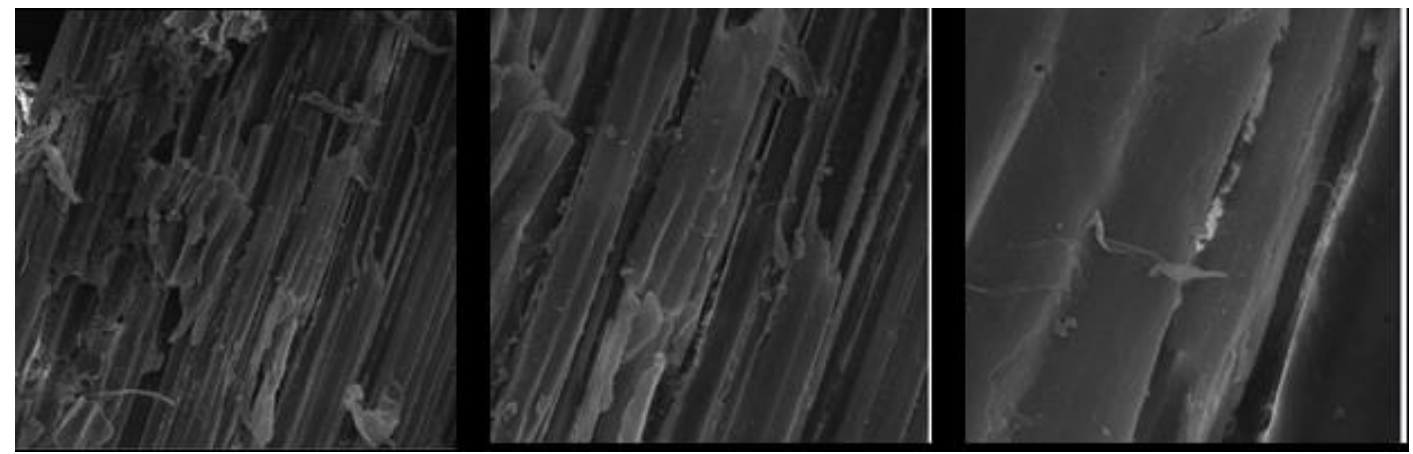

Figure 2. Acetylated wild cane with 500x magnification; 1000x and 5000x, respectively.

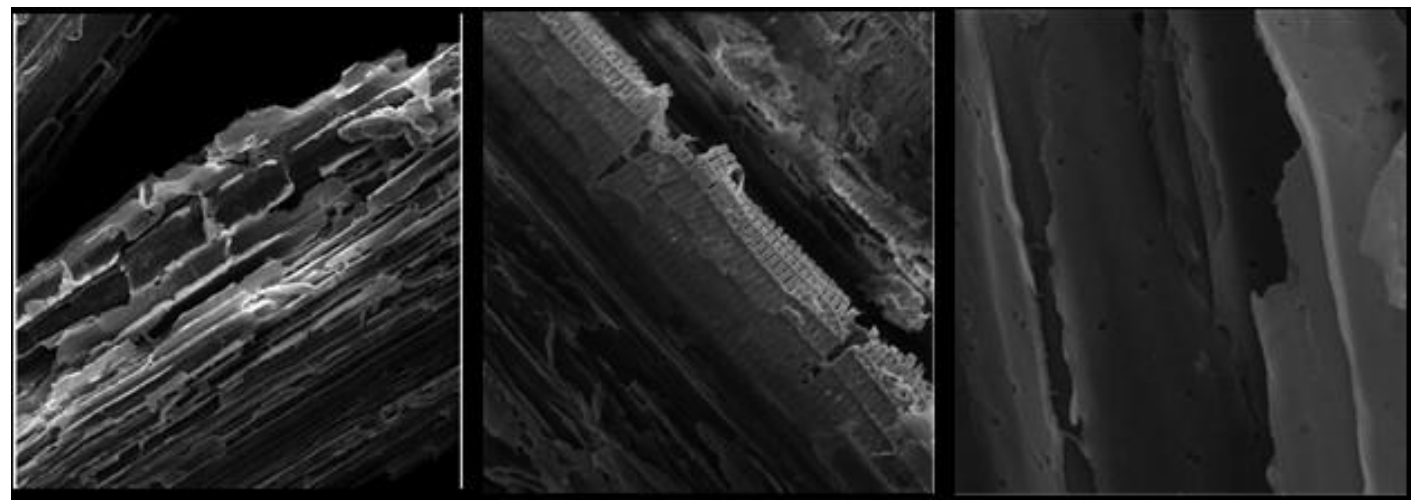

Figure 3. Wild cane treated with ionic liquid [2HEA] [Ac] with magnification of 500x; 1000x and 5000x, respectively.

Figure 2 shows wild cane fiber after acetylation. A slight change in part of the fiber structure, presenting a wrinkle surface, is observed after submitting it to treatment. This appearance can be attributed to the blanket of plant wax, hemicellulose, lignin, and impurities on the surface.

The acetylated fiber showed a smooth surface with the treatment, which promoted superficial cleaning and removed the parenchyma cell structure. Abdelwahab et al. (2017) also reported in their study that the chemical treatment (acid or base) had only a small superficial effect on palm fiber surface. Lopes et al. (2010a) studied the acetylation of sisal. They identified that the fibers presented a smoother surface, which is associated to elimination of substances that directly influence hydrophilicity, such as pectin, lignin, and wax present in fiber cuticles. According to Lopes et al. (2010b), the acetylation of curauá fiber made it possible to identify the formation of cellulose acetate particles when compared to untreated fiber.

The SEM microphotographs of wild cane treated with protic ionic liquid are shown in Figure 3.
The biomass studied after treatment exhibited fibrillar structures and, apparently, an increase in the fiber surface area. The 2-hydroxyethanolamine acetate clearly promoted an increase in the roughness and the number pores, which may favor good adsorption results. Miranda et al. (2019) studied the influence of several ionic liquids on the removal of lignocellulosic components in the crown of the pineapple, and were able to verify that the treatments with the ILs resulted in a more irregular and porous texture. The treatments with ionic liquids [2HEA][Ac] and [2HEA][Pr] caused structure elongation and a higher presence of pores, related to lignin removal. In addition, the authors noted that the cellulose structures were preserved.

\subsection{Fourier Transform Infrared Spectroscopy (FTIR)}

Figure 4 represents the infrared spectra of untreated and treated fibers, in the range from 4000 to $500 \mathrm{~cm}^{-1}$. FTIR showed the main functional groups present in the spectrum, besides evaluating the fiber surface modification after treatments, according to the behavior of the bands. 


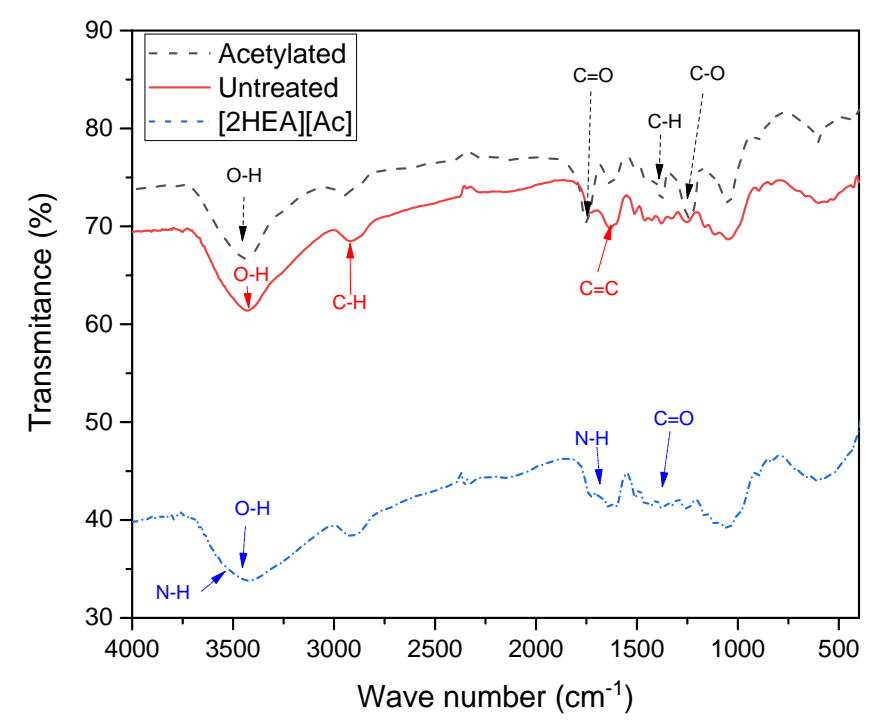

Figure 4. FTIR spectra of untreated and treated wild cane fibers.

For untreated wild cane, $\mathrm{O}-\mathrm{H}\left(3411 \mathrm{~cm}^{-1}\right)$ and C$\mathrm{H}\left(2898 \mathrm{~cm}^{-1}\right)$ groups were observed, which were assigned to polysaccharides, such as cellulose and hemicellulose. The band around 1650-1600 $\mathrm{cm}^{-1}$ refers to $C=C$ bond of lignin. The peaks found between the bands at 3600 and $3307 \mathrm{~cm}^{-1}$ is due to stretching vibration in the hydroxyl $(\mathrm{OH})$, which are associated to lignocellulosic structures of the fiber (Cai et al., 2019; Gorgulho et al., 2018; Hospodarova et al., 2018; Hu et al., 2019).

After acetylation treatment, variations were observed in the couplings of characteristic bands; a reduction of the hydroxyl groups $(\mathrm{O}-\mathrm{H})$ occurs, which can be evidenced by decrease in absorption intensity in the reference band. Successful esterification can be confirmed by the behavior of three important absorption bands around 1736, 1367 , and $1242 \mathrm{~cm}^{-1}$, related to stretching vibration in carbonyl $\mathrm{C}=\mathrm{O}, \mathrm{C}-\mathrm{H}$, and $\mathrm{C}-\mathrm{O}$ (Behnood et al., 2016; Gorgulho et al., 2018; Lopes et al., 2010b; Sun et al., 2004).

By comparison, one can observe that for treated fiber with the ionic liquid [2HEA][Ac], the increase in absorption range at $3600-3000 \mathrm{~cm}^{-1}$, represented by elongation in $\mathrm{OH}$, is incorporated in this band, and the compound can be an alcohol, phenol or carboxylic acid. The absorption peaks at 3600-3000 $\mathrm{cm}^{-1}$ and around $1750-1600 \mathrm{~cm}^{-1}$ are assigned to $\mathrm{N}$ $\mathrm{H}$ structure of primary amines, characteristic of ionic liquids based on ammonium neutralization (Trindade et al., 2019).
According to Rocha et al. (2014), the peaks at $1500-1250 \mathrm{~cm}^{-1}$ can be attributed to carbonyl elongation and flexural vibration in $\mathrm{N}-\mathrm{H}$ structure, indicating the presence of the amine group $\left(\mathrm{NH}_{3}\right)$. The range at $1700-1200 \mathrm{~cm}^{-1}$ corresponds to symmetrical vibration in $\mathrm{C}-\mathrm{H}$ bond, and the range $1260-700 \mathrm{~cm}^{-1}$ band indicates vibrations in C-C group.

\subsection{Thermogravimetric analysis (TGA and DTA)}

Figures 5, 6, and 7 represent the thermogravimetric (TGA / DTA) curves of untreated wild cane fiber, acetylated and treated with [2HEA][Ac] ionic liquid, respectively.

In Figure 5, a mass loss at about $4 \%$ occurs in region I from 25 to $95^{\circ} \mathrm{C}$, which is due to the loss of moisture. It is also possible to note that the fiber exhibited a thermal stability up to approximately $250^{\circ} \mathrm{C}$, where the degradation process begins in region II. Upon reaching a temperature of $450^{\circ} \mathrm{C}$, a mass loss of approximately $70 \%$ was obtained.

In Figure 6, one can observe in region I that the acetylated fiber showed a lower initial mass loss than untreated fiber. This behavior may be related to fiber esterification after the acetylation treatment, which led to the partial removal of water (Lopes et al., 2010b). It is possible to verify in Region II that the initial degradation temperature of the acetylated fiber was $230^{\circ} \mathrm{C}$, starting $20^{\circ} \mathrm{C}$ lower than the initial degradation 


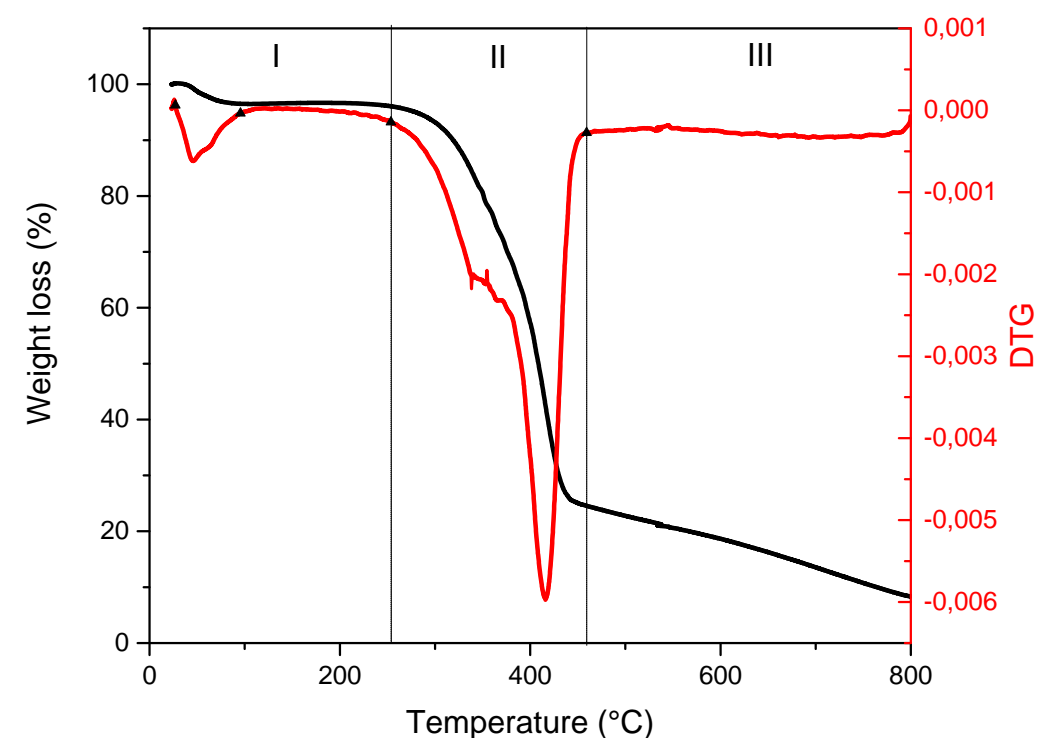

Figure 5. TGA / DTA curves of untreated wild cane.

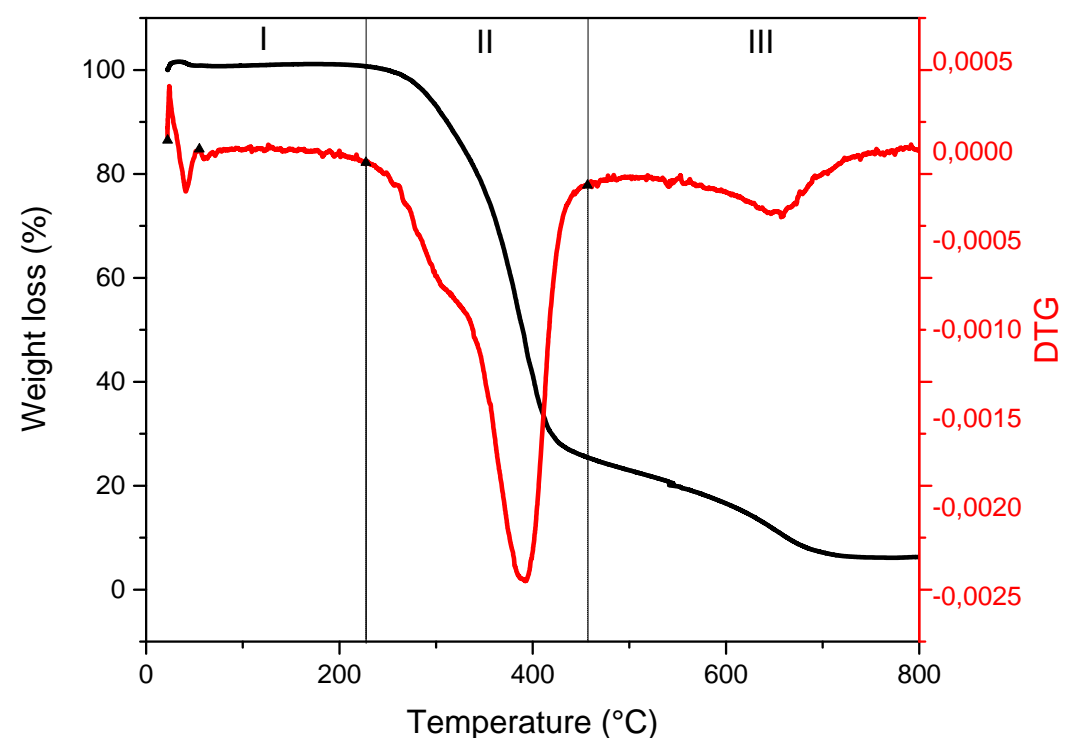

Figure 6. TGA / DTA curves of acetylated wild cane.

temperature of untreated fiber. This result evidences a lower thermal stability of the acetylated fiber in comparison to the untreated fiber.

Figure 7 illustrates the thermogravimetric curve of wild cane treated with ionic liquid. The curve first stage in region I, up to approximately $40^{\circ} \mathrm{C}$, is associated with the low humidity present in the fibers and presence of compounds such as organic acids and aliphatic hydrocarbons (Silva, 2017). The second event, which occurs in region $\mathrm{I}$, refers to the degradation of cellulose and hemicellulose, which are overlapping events with a maximum temperature of approximately $460^{\circ} \mathrm{C}$.

Analyzing DTA curves of the fibers, the presence of two distinct peaks indicates the occurrence of two stages in the thermal fiber degradation. In untreated fiber, the first peak present in region II refers to the predominant decomposition of hemicellulose components at temperatures ranging from 265 to $410^{\circ} \mathrm{C}$. The second peak present in region $\mathrm{II}$ is attributed to degradation of cellulose components. This peak is starts at $410^{\circ} \mathrm{C}$ and ends at about $450^{\circ} \mathrm{C}$. 


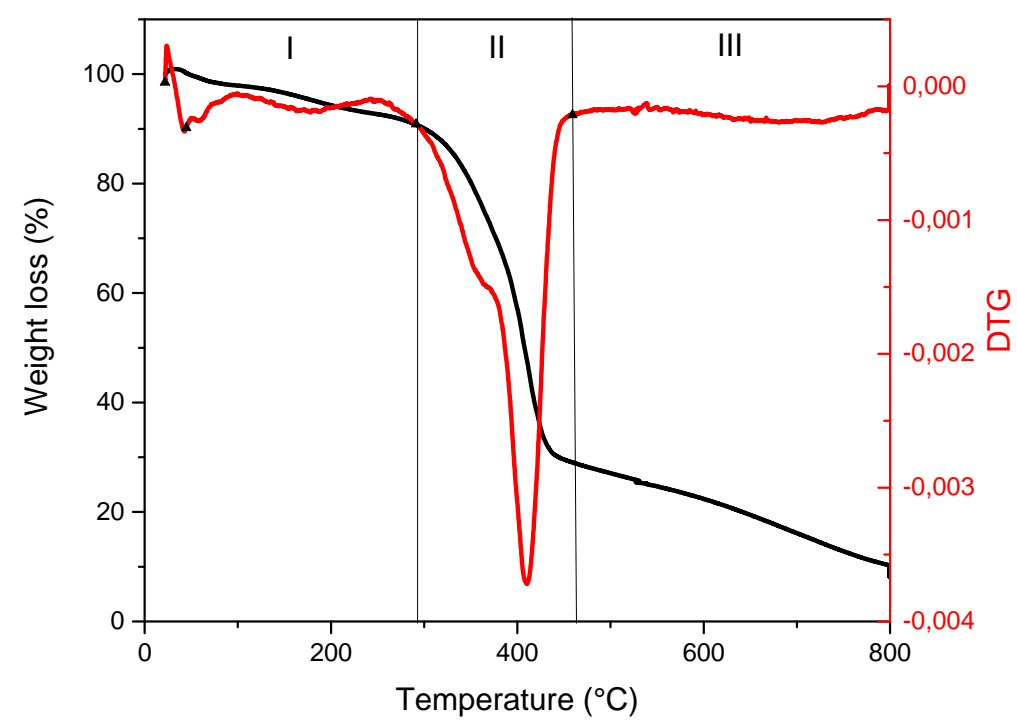

Figure 7. TGA / DTA curves of wild cane treated with ionic liquid.

The peaks in the acetylated fiber present in region $\mathrm{II}$, from 230 to $390^{\circ} \mathrm{C}$ and 390 to $460^{\circ} \mathrm{C}$, show that the acetylation of wild cane fiber anticipated the beginning of the process of hemicellulose and cellulose decomposition. For Yang et al. (2007), the lignin decomposition happens from $100^{\circ} \mathrm{C}$ to $806^{\circ} \mathrm{C}$, occurring both hemicellulose and cellulose degradation.

For biomass treated with [2HEA][Ac] ionic liquid, the decomposition of hemicellulose occurs in region II at approximately $290^{\circ} \mathrm{C}$ to $410^{\circ} \mathrm{C}$. The decomposition of cellulose in region III occurs from $410^{\circ} \mathrm{C}$ to $460^{\circ} \mathrm{C}$.

Lopes et al. (2010b) justified that thermodegradation of polysaccharides, such as cellulose, can occur due to the breakdown of glycosidic bonds (C-H, C-O, C-C) and decarboxylation and decarbonylation reactions, with formation of $\mathrm{C}-\mathrm{C}, \mathrm{C}=\mathrm{C}$ and $\mathrm{C}-\mathrm{O}$ bonds, as well as carbonyl and carboxyl groups. The loss of lignin mass occurs at high temperatures, and its degradation is related to dehydration, producing unsaturated derivatives with side chains and water release.

\subsection{X-Ray Diffraction (XRD)}

The crystallographic patterns of untreated wild cane fibers and after the acetylation and ionic liquid treatments indicated in Figure 8 , present characteristics of semicrystalline materials.

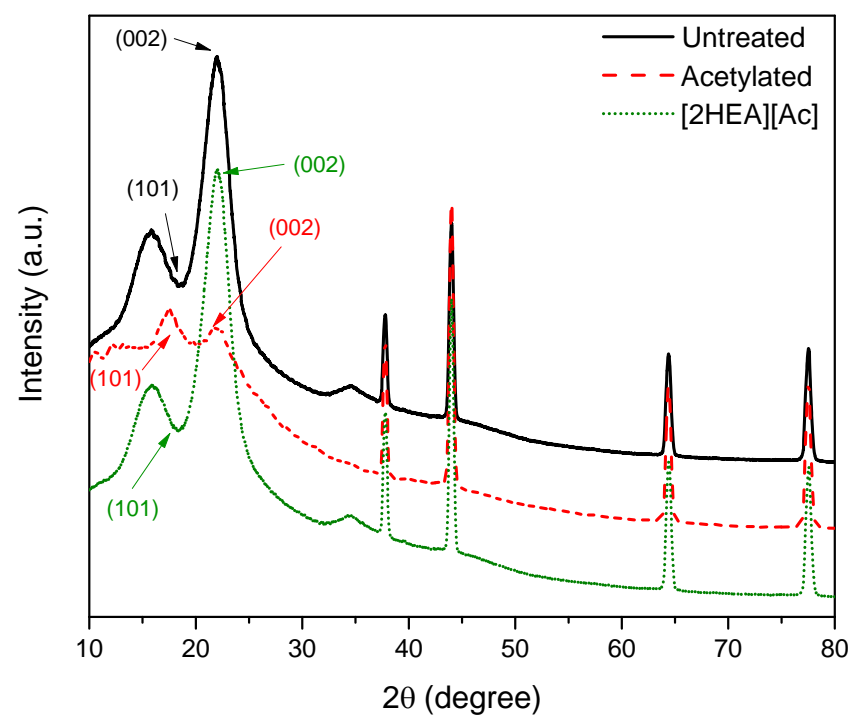

Figure 8. Diffractogram of the wild cane fibers. 
Characteristic peaks of type I cellulose can be observed. Peaks and the amorphous halo are located at $17^{\circ} \leq 2 \theta \leq 19^{\circ}$ and $22^{\circ} \leq 2 \theta \leq 23^{\circ}$, corresponding to the crystallographic planes (101) and (002) (Segal et al., 1959). Treatment with [2HEA][Ac] led to increased crystallinity, and may be associated with fiber swelling, which increases the packaging degree in cellulose chains. The opposite effect can be observed in acetylated wild cane, where the crystallinity index decreased significantly when compared to samples untreated and treated with ionic liquid.

To quantify the crystallinity change, the crystallinity index was calculated using Equation 1, with the maximum peak intensity of the crystallographic plane (002) attributed by the polymorphic crystal of cellulose I and the intensity at which the peak of amorphous region is found. The crystallinity index found for untreated wild cane was $44.8 \%$, about $29 \%$ higher than that of the acetylated fiber. Lopes et al. (2010b) found similar results, where the acetylated fiber showed an expressive decrease in crystallinity index. For wild cane treated with [2HEA][Ac], the crystallinity index was $67.5 \%$. George et al. (2015) explains that an increase in crystallinity index is often indicative of hemicellulose and lignin removal, and consequent increase of cellulose. Miranda et al. (2019) obtained an increase in crystallinity for the crown of pineapple treated with ionic liquid compared to the untreated sample. For protic ionic liquids [2HEA][Ac] and [2HEA][Pr] the authors obtained crystallinity index of approximately 50\% and $68 \%$, respectively, whereas the untreated fiber had an index of approximately $38 \%$. However, this event was not observed for the acetylated fiber, which can be attributed to the probable transformation of type I cellulose into type II cellulose, which is accompanied by a decrease in crystallinity (Silva, 2017). Cheng et al. (2012) reported that cellulose II can be obtained from cellulose $I$ in processes involving dissolution of cellulose in solvent, and that it is less recalcitrant.

\subsection{Compositional analysis}

The amount of cellulose, hemicellulose, and lignin of the untreated biomass, treated with acetylation and ionic liquid [2HEA][Ac] are shown in Table 3.

Untreated wild cane fiber contained $91.6 \%$ of structural components, such as cellulose, hemicellulose, and lignin; and $8.43 \%$ non-structural components such as waxes, fats, proteins, pectins, and other impurities. There are still no scientific reports measuring the chemical composition of wild cane, however, comparing it with grasses of the same family, a slight similarity in its composition can be observed. Rabelo et al. (2011) and Canilha et al. (2011) evaluated the chemical composition of sugarcane finding values in the range of $38-45 \%$ cellulose, $23-26 \%$ hemicellulose, and $19-25 \%$ lignin.

Acetylation promoted an almost total removal of hemicellulose and part of the lignin, increasing the cellulose content. Silva et al. (2009) reported that there are difficulties in separating the smaller components of the fiber due to its structural complexity. During the chemical process, the hemicellulose is degraded, completely or partially, along with the lignin matrix.

Treatment with [2HEA][Ac] did not promote a significant difference in the fiber. The results can be justified by the choice of protic ionic liquid used and the treatment conditions used, such as time and temperature (Brandt et al., 2010; El-Sayed, 2017; Miranda et al., 2019; Perez-Pimienta et al., 2015; Rocha et al., 2014; Verdía et al., 2014).

Table 3. Chemical composition of wild cane.

\begin{tabular}{lcccc}
\hline & Cellulose (\%) & Hemicellulose (\%) & Lignin (\%) & Others (\%) \\
\hline Untreated & 59.83 & 20.67 & 11.07 & 8.43 \\
Acetylated & 83.18 & 3.58 & 7.11 & 6.13 \\
[2HEA][Ac] & 62.21 & 19.43 & 9.92 & 8.44
\end{tabular}


Table 4. Crude oil characterization.

\begin{tabular}{lccc}
\hline \multicolumn{1}{c}{ Property } & Unit & Oil & Deviation \\
\hline Density & $\mathrm{g} / \mathrm{cm}^{3}$ & 0.9081 & \pm 0.00001 \\
Viscosity & $\mathrm{cP}$ & 17 & \pm 4.7 \\
\hline
\end{tabular}

Miranda et al. (2019) verified that the conditions applied at $100^{\circ} \mathrm{C}$ and $1 \mathrm{~h}$ for the treatment of the crown of the pineapple with protic ionic liquids did not cause significant modifications in the composition. The untreated pineapple crown had approximately $35 \%, 25 \%$, and $5 \%$ cellulose, hemicellulose, and lignin contents, respectively. In the biomass treated with [2HEA][Ac] the levels presented were of $38 \%, 29 \%$, and $2 \%$, respectively. Results suggest that the conditions used in the treatment did not remove the lignocellulosic components significantly.

\subsection{Crude oil characterization}

The results of the analyses of density and viscosity of the oil used in the adsorption tests are shown in Table 4.

The pour point was also evaluated, although it was not possible to determine its exact value due to the limitation in the minimum temperature of the thermostatic bath. The oil reached $-3.2^{\circ} \mathrm{C}$ during the analysis, still not reaching its pour point. Hence, at $26^{\circ} \mathrm{C}$, the oil adsorption tests showed good fluidity. The oil used presents ${ }^{\circ} \mathrm{API} 24$ being classified as medium (22.3> ${ }^{\circ} \mathrm{API}>31.1$ ) (Szklo, 2005).

\subsection{Kinetic models}

Figure 9 shows oil adsorption kinetics of the untreated, acetylated, and treated with ionic liquid fibers.

The average time to reach the maximum adsorption was 90 minutes for untreated wild cane, where sorption capacity remained constant. For untreated biomass, the maximum adsorption values reached $4.3 \mathrm{~g}$ oil $/ \mathrm{g}$ adsorbent.

It is possible to notice that the acetylation and ionic liquid treatments [2HEA][Ac] promoted a reduction in the oil sorption capacity, which both presented maximum values of $3.5 \mathrm{~g}$ oil / g adsorbent. This reduction can be justified on the basis of composition analysis. The results indicated that the acetylated fiber presented a significant reduction of the hemicellulose (hydrophilic) content, and a slight decrease of the lignin

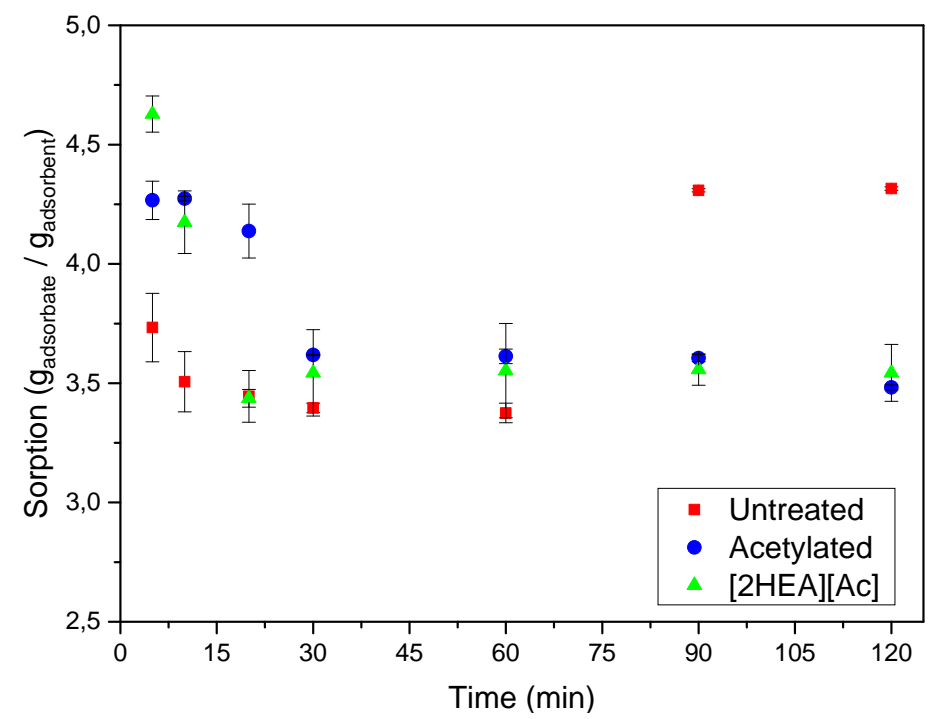

Figure 9. Experimental data for kinetics of oil adsorption. Error bars represent the standard deviation of duplicate measurements. 
(oleophilic) content, which increased the percent of cellulose (hydrophilic), characteristics of the mercerization pre-treatment (Bledzki \& Gassan, 1999; Mohanty et al., 2001; Ray et al., 2001). The fact that the acetylation treatment fails to remove the cellulose content may be related to the previously established conditions for the treatment, which resulted in a partial acetylation in the reaction. The addition of more catalyst in the process could cause an increase in the reaction rate, being able to degrade the cellulose, providing a more hydrophobic fiber (Bledzki et al., 2008).

For fiber treated with the ionic liquid [2HEA][Ac], practically there was no change in composition by comparing it with the untreated fiber. The reduction in the adsorption capacity of the treated fiber may be associated to temperature and contact time conditions during the treatment, and the choice of using a protic ionic liquid as well.
Perez-Pimienta et al. (2006) reported that factors such as temperature and time, and also the choice of cation and anion types, can make significant differences in the delignification processes during treatment (Brandt et al., 2013; Brandt et al., 2010; El-Sayed, 2017; Liu et al., 2016; Miranda et al., 2019; Semerci \& Güler, 2019; Verdía et al., 2014).

Several studies have demonstrated the efficiency of cellulose removal for aprotic ionic liquids such as 1-ethyl-3-methylimidazolium acetate [C2mim][OAc] and as 1-butyl-3methylimidazolium acetate [C4mim][Ac] (Cheng et al., 2012; Zhang et al., 2014). In a study conducted by Cruz et al. (2013) with 1-ethyl-3methylimidazolium acetate [C2mim][OAc], the XRD analysis shows a decrease in crystallinity, proving the removal of cellulose in the biomass. Zhang et al. (2014) and Xie et al. (2018) found similar results for biomass using the ionic liquid [C4mim][Ac].
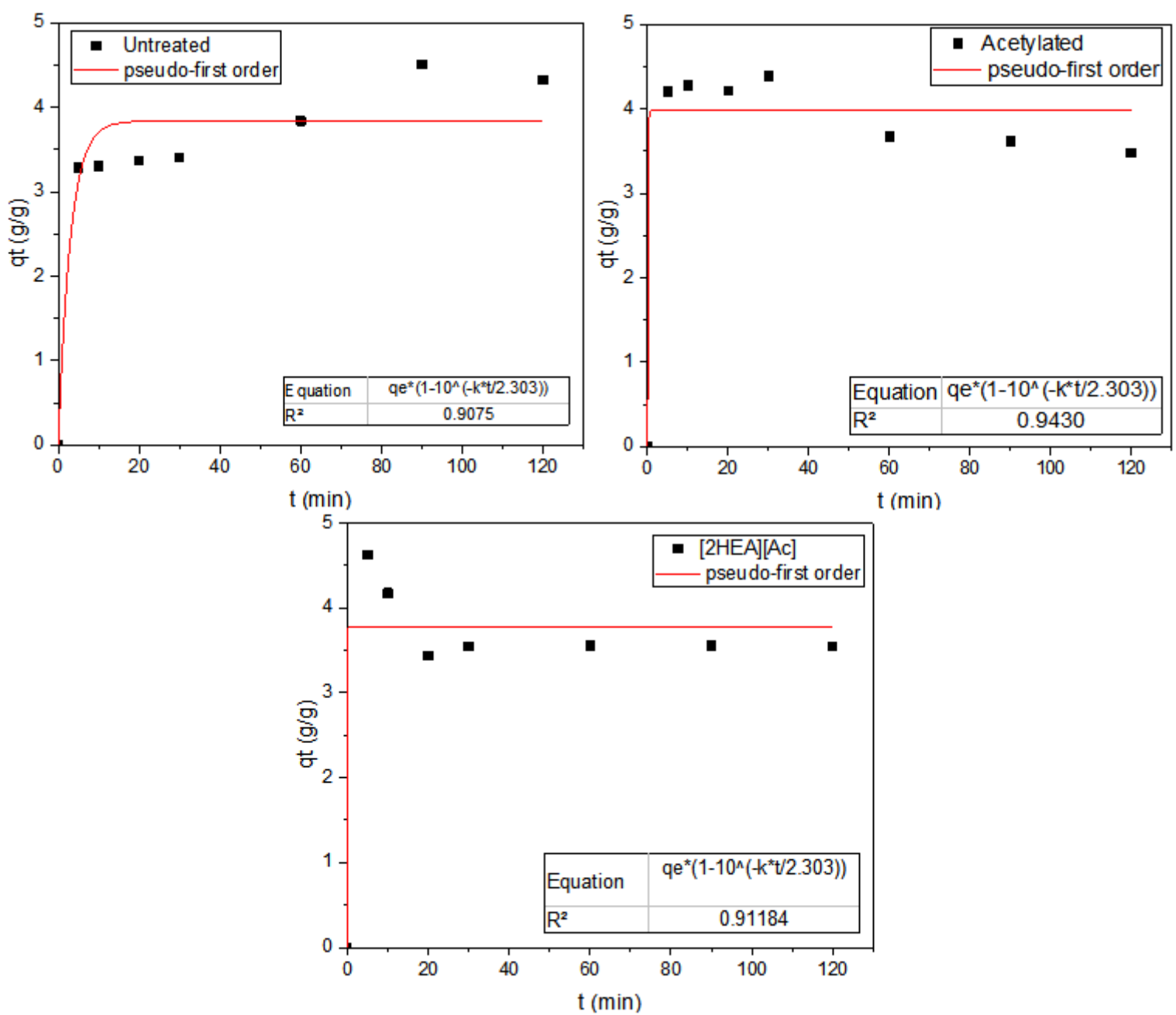

Figure 10. Pseudo-first-order model for untreated wild cane, acetylated, and treated with [2HEA][Ac], respectively. 
Table 5. Kinetic parameters and regression coefficients - Pseudo-first order.

\begin{tabular}{lcccc}
\hline \multirow{2}{*}{ Fiber } & \multicolumn{3}{c}{ Kinetic parameters } & Correlation coefficient \\
\cline { 2 - 4 } & $\mathrm{q}_{\text {e cal. }}(\mathrm{g} / \mathrm{g})$ & $\mathrm{q}_{\mathrm{e} \text { exp }}(\mathrm{g} / \mathrm{g})$ & $\mathrm{k}_{1}\left(\mathrm{~min}^{-1}\right)$ & $\mathrm{R}^{2}$ \\
\hline Untreated & 3.8397 & 4.3083 & 0.3356 & 0.9075 \\
Acetylated & 3.9817 & 3.6187 & 10.0617 & 0.9430 \\
{$[2 \mathrm{HEA}][\mathrm{Ac}]$} & 3.7766 & 3.5434 & 31.9472 & 0.9118 \\
\hline
\end{tabular}

Therefore, the protic ionic liquid [2HEA][Ac] may have properties that suggest a higher lignin removal capacity of the biomass, but not of cellulose and hemicellulose. However, the temperature $\left(80^{\circ} \mathrm{C}\right)$ and time $(2 \mathrm{~h})$ conditions used in the treatment were not sufficient to promote the removal of even a significant amount of the lignin. The higher quantity of hydrophilic components, such as cellulose and hemicellulose, resulted in a higher affinity for water, reducing the oil sorption capacity.

The sorption kinetic study, using untreated wild cane fiber and after treatments, were also applied to the experimental data to evaluate the process of oil adsorption. The kinetic models applied to this work are pseudo-first order, pseudo-second order, and intraparticle diffusion.

Figure 10 shows sorption kinetics curves by pseudo-first-order model for the untreated, acetylated, and ionic liquid treated fiber.

The regression coefficient $\left(R^{2}\right)$ values for different kinetic graphs were used to determine the mechanism that operate during the adsorption process. Onwuka et al. (2016) state that $R^{2}$ values between $0.43-0.83$ are considered moderate to high. Although the $\mathrm{R}^{2}$ values obtained for the model were relatively high, it allows us to recognize that the pseudo-first order model does not fit for any of the three studied fibers, due to correlation coefficients not being so close to 1 . Similar results were found for the same model in Wang et al. (2015), where the $R^{2}$ values were below 0.9 using the rice husk fiber and in Onwuka et al. (2016), for different temperatures, found $R^{2}$ values between 0.051 and 0.5749 , confirming that the model does not fit to experimental dada. The kinetic parameters of the pseudo-first-order model and the correlation coefficients obtained are presented in Table 5.

Figure 11 shows the sorption kinetics curves by pseudo-second order model for the untreated, acetylated, and ionic liquid treated fiber.

Note that the $\mathrm{R}^{2}$ values for the untreated and acetylated fibers are above 0.99 , indicating that the kinetic model of pseudo-second order is suitable to describe the oil sorption. The same was found by Al Zubaidi et al. (2016), who used tire residues to adsorb crude oil in water. The kinetic parameters of the pseudo-first order model and the correlation coefficients obtained are shown in Table 6.

Table 6. Kinetic parameters and regression coefficients - Pseudo-second order.

\begin{tabular}{ccccc}
\hline \multirow{2}{*}{ Fiber } & \multicolumn{3}{c}{ Kinect parameters } & Correlation coefficient \\
\cline { 2 - 5 } & $\mathrm{q}_{\mathrm{e} \text { cal. }}(\mathrm{g} / \mathrm{g})$ & $\mathrm{q}_{\mathrm{e} \text { exp }}(\mathrm{g} / \mathrm{g})$ & $\mathrm{k}_{2}\left(\mathrm{~g} / \mathrm{g} \cdot \mathrm{min}^{-1}\right)$ & $\mathrm{R}^{2}$ \\
\hline Untreated & 4.4589 & 4.3083 & 0.0536 & 0.9919 \\
Acetylated & 3.4764 & 3.6187 & 0.1183 & 0.9977 \\
{$[2 \mathrm{HEA}][\mathrm{Ac}]$} & 3.5281 & 3.5434 & 0.5672 & 0.9998 \\
\hline
\end{tabular}



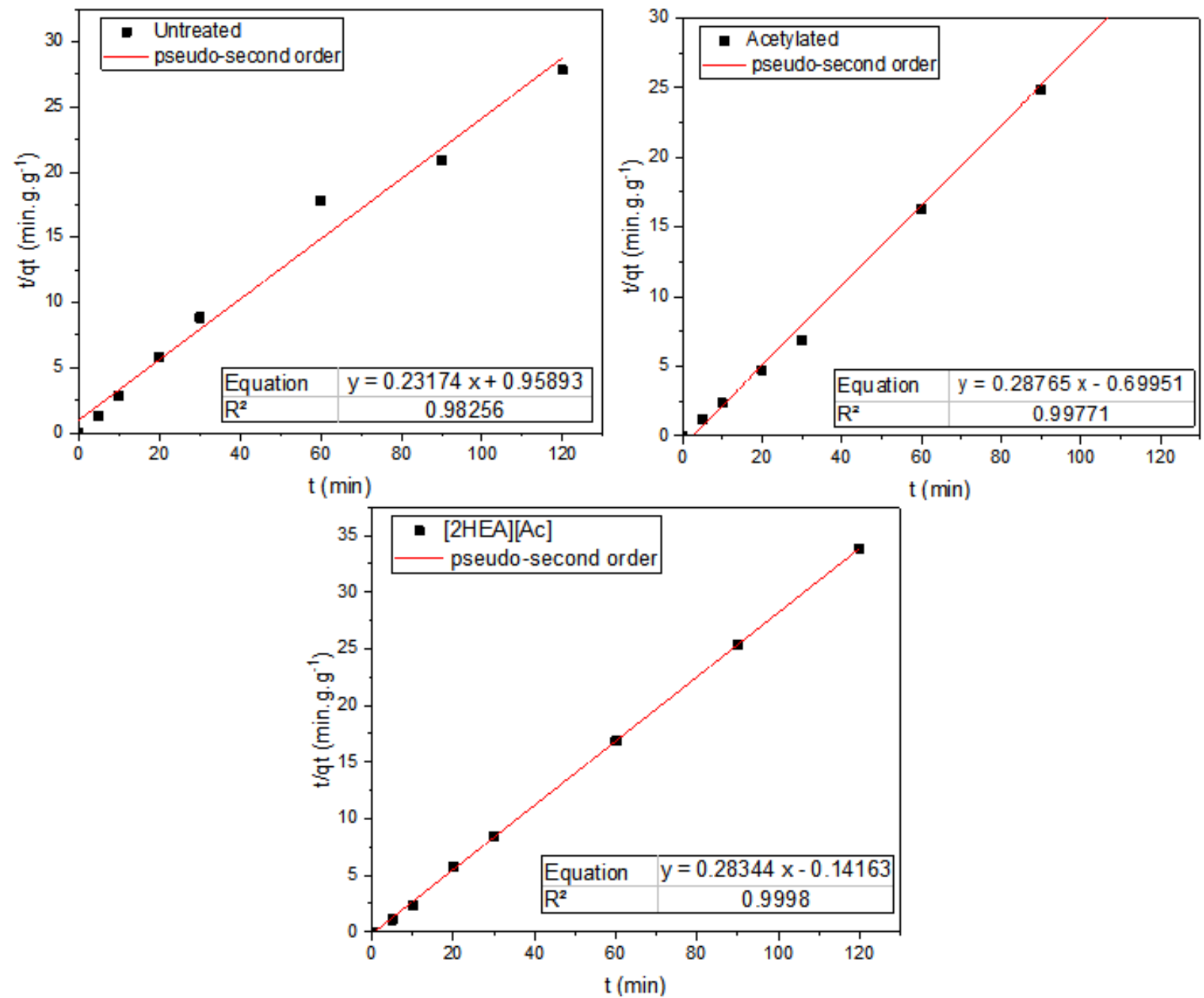

Figure 11. Pseudo-second order model for untreated wild cane, acetylated, and treated with [2HEA][Ac], respectively.

The intraparticle diffusion model for untreated, acetylated, and ionic liquid treated fiber are shown in Figure 12.

The regression coefficients $\left(R^{2}\right)$ for intraparticle diffusion model were lower than that found for other models that obtained $R^{2}$ values above 0.9. This indicates that the model is not suitable for describing oil sorption. One can observe in the graph qt versus $\mathrm{t}^{0.5}$ that there is no linear relation over the entire time band, indicating that there is more than one factor besides the diffusion that affects the adsorption. The kinetic parameters of the intraparticle diffusion model and the correlation coefficients obtained are shown in Table 7.

Thus, after analyzing the proposed kinetic

Table 7. Kinetic parameters and correlation coefficients - Intraparticle diffusion.

\begin{tabular}{lccc}
\hline \multirow{2}{*}{ Fiber } & \multicolumn{2}{c}{ Kinect parameters } & Correlation coefficient \\
\cline { 2 - 4 } & $\mathrm{k}_{\mathrm{i}}\left(\mathrm{g} / \mathrm{g} \cdot \mathrm{min}^{0.5}\right)$ & $\mathrm{C}^{\prime}(\mathrm{g} / \mathrm{g})$ & $\mathrm{R}^{2}$ \\
\hline Untreated & 0.6969 & 2.0369 & 0.8398 \\
Acetylated & -0.4783 & 5.1366 & 0.7436 \\
[2HEA][Ac] & -0.4970 & 4.9766 & 0.5579 \\
\hline
\end{tabular}



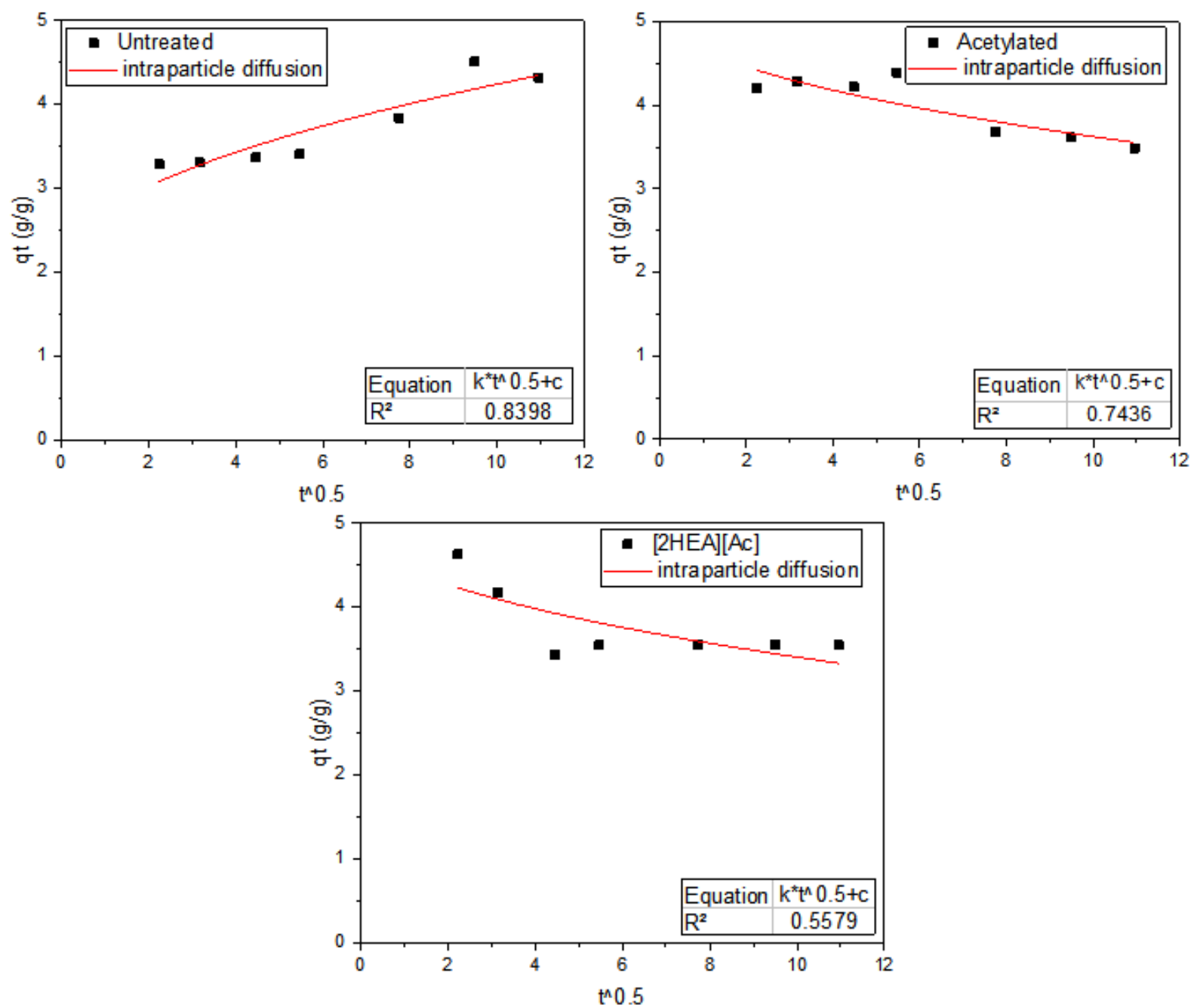

Figure 12. Intraparticle diffusion model for untreated wild cane, acetylated, and treated with

[2HEA][Ac], respectively.

models, one can state that the pseudo-second order model, which assumes the limiting step of the adsorption process is the chemical sorption, is the best model studied to describe the process of oil adsorption using untreated wild cane, acetylated, and treated with ionic liquid. This conclusion can be defined because the $\mathrm{R}^{2}$ were the closest to 1 for the analyzed biomasses (Cai et al., 2019; Hu et al., 2019; Pimentel et al., 2011; Wang et al., 2015).

\subsection{Sorption Isotherms}

The adsorption isotherms are essential to search informations about the adsorption process. Considering the kinetic results as a reference, the estimated time for the adsorption equilibrium to be reached for the untreated fiber was 90 minutes, whereas the acetylated and treated fiber with ionic liquid was 30 minutes. After the predetermined times for each fiber, the equilibrium concentration was determined, and the adsorptive capacity of wild cane was calculated.

Figure 13 shows the results obtained with the adsorption isotherms for untreated wild cane fiber, acetylated, and treated with ionic liquid, for the Langmuir, Freundlich, Sips, and Toth models.

The saturation for untreated wild cane was reached with $6 \mathrm{~mL}$ of oil and $74 \mathrm{~mL}$ of water, reaching a maximum adsorption capacity of $3.8 \mathrm{~g}$ oil / $\mathrm{g}$ adsorbent. The acetylated fiber reached equilibrium with $8 \mathrm{~mL}$ of oil and $72 \mathrm{~mL}$ of water, as well as the fiber treated with [2HEA][Ac], and its maximum adsorption capacities were $4.4 \mathrm{~g}$ oil / $\mathrm{g}$ adsorbent and $3.7 \mathrm{~g}$ oil / g adsorbent, respectively. The results suggest that the acetylated fiber showed an increase in the adsorption capacity, while the fiber treated with the ionic liquid 


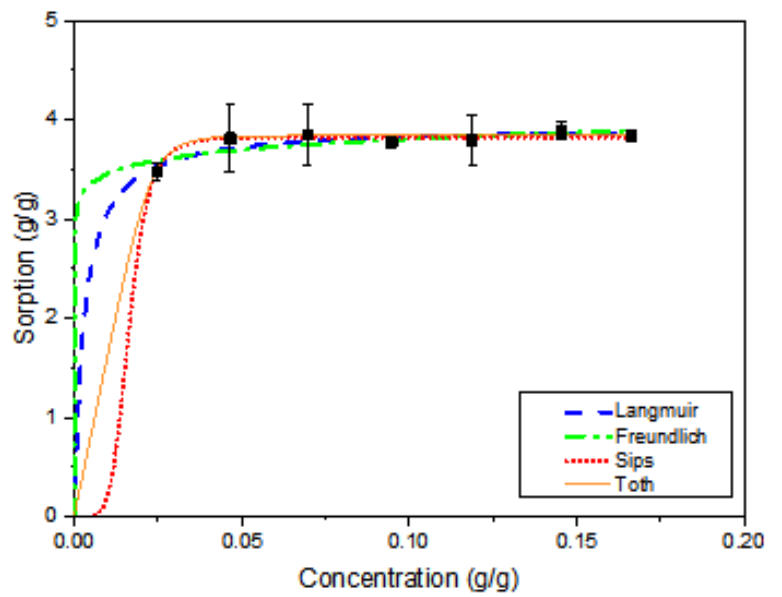

a)

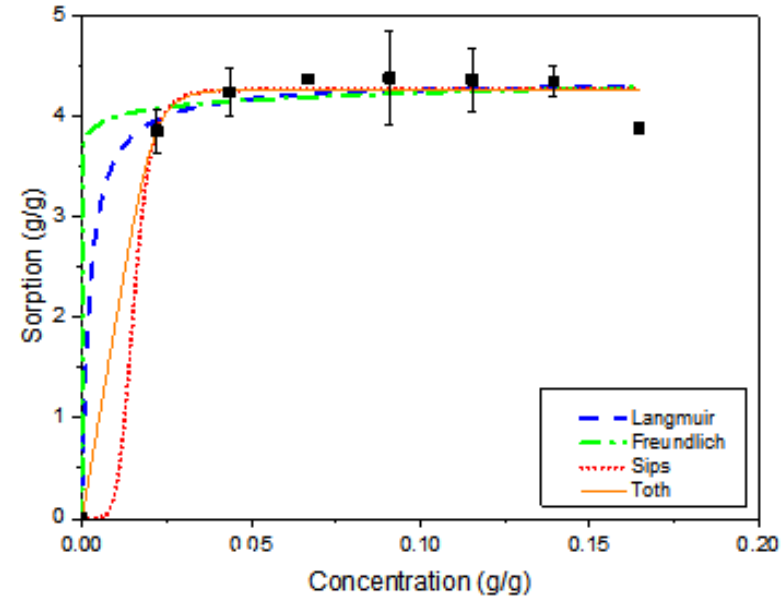

b)

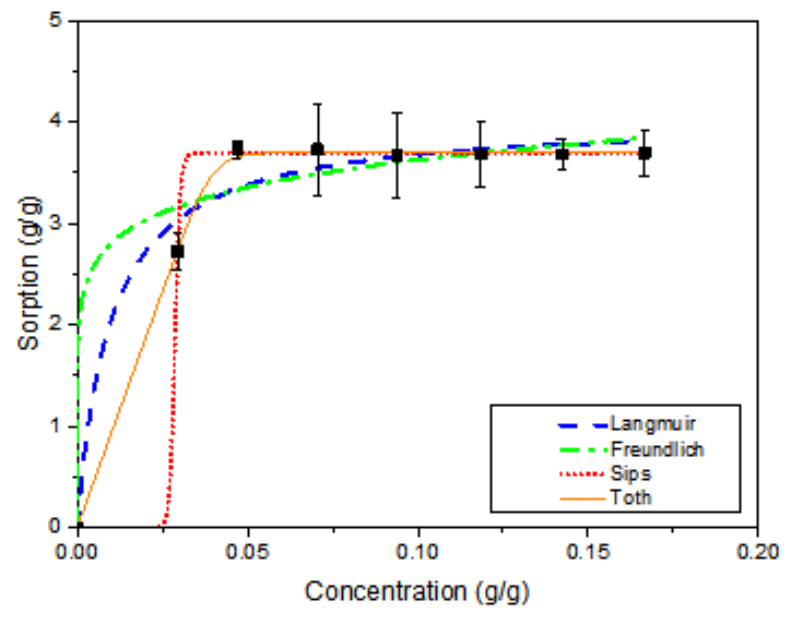

c)

Figure 13. Isotherms sorption models by wild cane fiber a) untreated, b) acetylated, c) [2HEA][Ac].

$[2 \mathrm{HEA}][\mathrm{Ac}]$, did not change its capacity. The equilibrium data, by comparison with the kinetic study, can be justified by the high deviations obtained, which can end up generating an error of interpretation, since it suggests that the acetylation promoted an improvement in the biomass adsorption capacity.

Table 8 shows sorption capacity (q) for the untreated, acetylated, and treated fibers with [2HEA][Ac].

Table 8. Parameters and deviations models for adsorption of oil by untreated, acetylated, and [2HEA][Ac] fibers.

\begin{tabular}{ccccc}
\hline Model & Parameters & Untreated & Acetylated & {$[2 \mathrm{HEA}][\mathrm{Ac}]$} \\
\hline \multirow{4}{*}{ Sips } & $\mathrm{q}_{\mathrm{ms}}(\mathrm{g} / \mathrm{g})$ & 3.8284 & 4.2707 & 3.6932 \\
& $\mathrm{~b}(\mathrm{~mL} / \mathrm{g})$ & 61.1232 & 65.1740 & 34.8768 \\
& $\mathrm{~N}$ & 0.1805 & 0.1652 & 0.0269 \\
& $\mathrm{R}^{2}$ & 0.9991 & 0.9835 & 0.9996 \\
\hline \multirow{4}{*}{ Toth } & $\mathrm{q}_{\mathrm{mT}}(\mathrm{g} / \mathrm{g})$ & 3.8284 & 4.2709 & 3.6992 \\
& $\mathrm{k}_{\mathrm{T}}(\mathrm{mL} / \mathrm{g})$ & $4.6 \mathrm{E}+9$ & $2.5 \mathrm{E}+10$ & $4.6 \mathrm{E}+15$ \\
& $\mathrm{~m}_{\mathrm{T}}$ & 5.9428 & 6.2581 & 11.1829 \\
& $\mathrm{R}^{2}$ & 0.9991 & 0.9835 & 0.9990 \\
\hline \multirow{3}{*}{ Langmuir } & $\mathrm{k}_{\mathrm{L}}(\mathrm{mL} / \mathrm{g})$ & 354.1236 & 460.4941 & 103.2944 \\
& $\mathrm{q}_{\mathrm{mL}}(\mathrm{g} / \mathrm{g})$ & 3.9372 & 4.3591 & 4.0305 \\
& $\mathrm{R}^{2}$ & 0.9976 & 0.9820 & 0.9704 \\
\hline \multirow{3}{*}{ Freundlich } & $\mathrm{k}_{\mathrm{F}}\left(\left(\mathrm{g} \cdot \mathrm{g}^{-1}\right)\left(\mathrm{mL} \cdot \mathrm{g}^{-1}\right)^{1 / \mathrm{n}}\right)$ & 4.1936 & 4.4876 & 4.6885 \\
& $\mathrm{n}_{\mathrm{F}}$ & 23.9407 & 40.2618 & 8.9459 \\
& $\mathrm{R}^{2}$ & 0.9958 & 0.9782 & 0.9567 \\
\hline
\end{tabular}


The results obtained for untreated wild cane, acetylated, and treated with the ionic liquid [2HEA][Ac] fit the studied models well, obtaining values of regression correlation coefficients $\left(R^{2}\right)$ close to 1 . However, both Sips and Toth models were the ones that presented the best adjustments to the experimental data, with $R^{2}(0.9991,0.9835$, $0.9999)$ and $(0.9999,0.9835,0.9999)$, respectively. Both models were developed to optimize the Langmuir and Freundlich models and assume an adsorption in heterogeneous surfaces, being therefore models that describe well the liquid-solid sorption system (Kumar \& Natarajan, 2016; Terzyk et al., 2003).

\section{CONCLUSIONS}

In the kinetic adsorption study, it was possible to conclude that the time for the untreated wild cane to reach equilibrium was 90 minutes, while the acetylated and [2HEA][Ac] treated fiber reached it in 30 minutes. Results show that the untreated biomass presented a maximum adsorption capacity of $4.3 \mathrm{~g}$ of oil/g adsorbent whereas the acetylated and [2HEA][Ac] treated biomass showed a reduction in maximum adsorption capacity, reaching values of $3.5 \mathrm{~g}$ oil/g adsorbent. The kinetic model that best fit the experimental data was pseudo-second order, presenting $R^{2}$ values above 0.99 for the untreated, acetylated, and [2HEA][Ac] treated fibers, which indicate that the adsorption is mainly chemical.

The determination of sorption isotherm values indicates that the experimental data can be described by the Sips and Toth models, with correlation coefficients $\left(R^{2}\right)$ of $(0.9991,0.9835$, 0.9999) and (0.9999; 0, 9835 and 0.9999), respectively, for untreated, acetylated, and [2HEA][Ac] treated, indicating adsorption on heterogeneous surfaces.

The experimental data obtained shows that the treatment conditions were not ideal, since they caused a reduction in biomass sorption capacity. The acetylation treatment was not able to remove cellulose (hydrophilic) due to the partial acetylation in the reaction. For the [2HEA][Ac], ionic liquid, the temperature used and the low contact time ( 2 hours) in the treatment, besides the protic cation [2HEA] used, may justify the low influence of the treatment on fiber properties, confirmed by the biomass characterization analyses.
Through the Scanning Electron Microscopy (SEM) it was possible to observe the structural morphology behavior of the untreated, acetylated, and ionic liquid treated fibers. For the acetylated fiber, it was possible to observe a slight modification in part of the wild cane structure, resulting from the removal of waxes and impurities. In the [2HEA][Ac] treated fiber it was possible to notice a greater morphological alteration, where the fiber had a rougher appearance and a larger number of pores, which should improve the biomass sorption capacity.

The FTIR spectra analysis allowed us to identify the functional groups adhered to the fiber and its modifications, through the bands behavior, before and after the acetylation and [2HEA][Ac] treatments. The acetylated fiber spectrum showed increases in the bands associated to carboline, as a function of the acetyl group connections; a characteristic process of the acid treatment. The treatment with [2HEA][Ac] ionic liquid provided an increase in the absorption range in the corresponding bands to the $\mathrm{N}-\mathrm{H}$ structure of the primary amines, in addition to the carbonyl elongation in the corresponding band.

By comparison, thermogravimetric analyses made it possible for us to observe that the degradation temperatures were slightly lower to untreated wild cane, indicating that treatments caused a small reduction in biomass thermal stability. Treatments of acetylation and with [2HEA][Ac] ionic liquid caused a reduction in the hygroscopic characteristic of the fiber.

The wild cane diffractogram allowed us to conclude that the [2HEA][Ac] treated fiber led to an increase in crystallinity due to the increase packing of the cellulose chains. This result was also confirmed by the composition analysis that shows lignin and hemicellulose removal causing an increase in cellulose percentage. The acetylated fiber presented a significant decrease in the crystallinity index due to the transformation of type I cellulose into type II cellulose.

Although the results indicate that the treatments did not contribute to the wild cane fiber adsorption capacity, which was shown to be a potential sorbent to be used for the oil removal in an aqueous environment in the untreated form. In addition, the fact that biomass does not require treatment makes the process more agile, simple, 
and inexpensive, since the absence of chemical reagents implies lower added cost to the process and lower environmental hazard risks.

\section{ACKNOWLEDGMENTS}

The authors gratefully acknowledge the financial support provided by the National Council for Scientific and Technological Development (CNPq) (Grant 306640/2016-3 and Project 438036/20182), the Coordination for the Improvement of Higher Education Personnel (CAPES), the State of Bahia Research Foundation (FAPESB), the Federal Institute of Education, Science and Technology of Bahia (IF Baiano - Catu), Federal Institute of Education, Science, and Technology of Bahia (IFBA), SENAI CIMATEC, and the Laboratory of Oil and Gas (LAPEG) for making the analysis available. We also would like to recognize the Artisan Association of Praia Grande (Ilha de Maré) for donating the wild cane used in the samples studied.

\section{REFERENCES}

Abdelwahab, O. Assessment of raw luffa as a natural hollow oleophilic fibrous sorbent for oil spill cleanup, Alexandria Engineering Journal, v.53, p. 213-218, 2014.

https://doi.org/10.1016/j.aej.2013.11.001

Abdelwahab, O.; Nars, S. M.; Thabet W. M. Palm fibers and modified palm fibers adsorbents for different oils. Alexandria Engineering Journal, v.56, p. 749-755, 2017.

https://doi.org/10.1016/i.aej.2016.11.020

Achinivu, E. C.; Howard, R. M.; Guoging, L. I.; Gracz, H.; Henderson, W. A. Lignin extraction from biomass with protic ionic liquids. Green Chemistry, v.16, p. 1114-1119, 2014.

https://doi.org/10.1039/C3GC42306A

Almeida, F. B. P. S.; Meili, L.; Soletti, J. I.; Esquerre, K. P. S. O. R.; Ribeiro, L. M. O.; Silva, C. E. F. Oil produced water treatment using sugarcane solid residue as biosorbent. Revista Mexicana de Ingeniería Química v. 18(1), p. 27-38, 2019. https://doi.org/10.24275/uam/izt/dcbi/revmexingquim/ 2019v18n1/Almeida
Al Zubaidi, I. A. H.; Al Tamimi, A. K.; Ahmed, H. Remediation of water from crude oil spill a fibrous sorbent. Environmental Technology \& Innovation. v. 6, p. 105-114, 2016.

https://doi.org/10.1016/i.eti.2016.08.002

ASTM D5002-18e1, Standard Test Method for Density, Relative Density, and API Gravity of Crude Oils by Digital Density Analyzer. ASTM International, West Conshohocken, PA, 2018.

ASTM D445-18, Standard Test Method for Kinematic Viscosity of Transparent and Opaque Liquids (and Calculation of Dynamic Viscosity). ASTM International, West Conshohocken, PA, 2018.

ASTM D97-17b, Standard Test Method for Pour Point of Petroleum Products, ASTM International, West Conshohocken, PA, 2017.

Azzam, R.; Madkour, T. M. Molecular design, synthesis, and analysis of new hydrophobic sea foams with augmented uptake capacity. International Journal Energy Environment, v.2, p.56-65, 2008.

Baghya, N. P.; Prashanth, P. A.; Raveendra, R. S.; Sathyanarayani, S.; Ananda, S.; Nagabhushana, B. M.; Nagabhushana, H. Adsorption of hazardous cationic dye onto the combustion derived $\mathrm{SrTiO3}$ nanoparticles: Kinetic and isotherm studies. Journal of Asian Ceramic Societies, v. 4(1), p. 6874, 2015. https://doi.org/10.1016/i.jascer.2015.11.005

Behnood, R.; Anvaripour, B.; Jaafarzadeh, N.; Farasati, N. Oil spill sorption using raw and acetylated sugarcane bagasse. Journal of Central South University, v. 23(7), p. 1618-1625, 2016. https://doi.org/10.1007/s11771-016-3216-8

Bledzki, A. K.; Gassan, J. Composites reinforced with cellulose based fibres. Progress in Polymer Science, v.24, p. 221-274, 1999.

https://doi.org/10.1016/S0079-6700(98)00018-5

Bledzki, A. K.; Mamun, A. A.; Lucka-gabor, M.; Gutowski, V. S. The effects of acetylation on properties of flax fibre and its polypropylene composites. eXPRESS Polymer Letters, v.2(6), p. 413-422, 2008.

https://doi.org/10.3144/expresspolymlett.2008.50 
Brandt, A.; Gräsvik, J.; Halletta, J. P.; Welton, T. Deconstruction of lignocellulosic biomass with ionic liquids. Green Chemistry, v.1, p. 550-583, 2013. https://doi.org/10.1039/c2gc36364j

Brandt, A.; Hallett, J. P.; Leak, D. J.; Murphy, R. J.; Welton, T. The effect of the ionic liquid anion in the pretreatment of pine wood chips. Green Chemistry, v. 12, p. 672-679, 2010.

https://doi.org/10.1039/b918787a

Cai, L.; Zhang, Y.; Zhou, Y.; Zhang, X.; JI, L.; Song, W.; Zhang, H.; Liu, J. Effective Adsorption of Diesel Oil by Crab-Shell-Derived Biochar Nanomaterials. Revista Materials, v.18(1), p. 27-38, 2019.

Canilha, L.; Santos, V. T. O.; Rocha, G. J. M. A study on the pretreatment of a sugarcane bagasse sample with dilute sulfuric acid. Journal of Industrial Microbiology and Biotechnology, v. 38, p. 1467-1475, 2011. https://doi.org/10.1007/s10295-010-0931-2

Cao, S.; Dong, T.; Xu, G.; Wang, F-M. Oil spill cleanup by hydrophobic natural fibers. Journal of Natural Fibers, v. 14, p. 727-735, 2017. https://doi.org/10.1080/15440478.2016.1277820

Chen, C. H.; Saleemi, S.; Liu, X.; Qiu, Y.; Xu, F. Hydrophobic lipophilic modified cotton fabric for oil absorption applications, Journal of Natural Fibers, v. 17(1), p. 1-9, 2018.

https://doi.org/10.1080/15440478.2018.1476946

Cheng, G.; Varanasi, P.; Arora, R.; Stavila, V.; Simmons, B. A.; Kent, M. S.; Singh, S. Impact of ionic liquid pretreatment conditions on cellulose crystalline structure using 1-Ethyl-3methylimidazolium acetate. The Journal of Physical Chemistry B, v. 116, p. 10049-10054, 2012. https://doi.org/10.1021/jp304538v

Cortez, J. S. A.; Kharisov, B. I.; Serrano, T.; González, L. T.; Kharissova, O. V. Hydrophobization and evaluation of absorption capacity of Aloevera,Opuntiaficus indica and Gelidium for oil spill cleanup, Journal of Dispersion Science and Technology, v. 40, p. 884 891, 2018. https://doi.org/10.1080/01932691.2018.1488593

Costa, E.; Silva, A.; Mattedi, S. Evaluation of ionic liquid treated sisal (agave sisalana) fiber as sorbent in biodiesel spill. IOP Conf. Series: Materials Science and Engineering, 348, 2018. https://doi.org/10.1088/1757-899X/348/1/012006
Cruz, A.; Scullin, C.; MU, C.; Cheng, G.; Stavila, V.; Varanasi, P.; Xu, D.; Mentel, J.; Chuang, Y. Impact of high biomass loading on ionic liquid pretreatment. Biotechnology for Biofuels, v. 6, p. 1-10, 2013. https://doi.org/10.1186/1754-6834-6-52

Daniel, A. B.; Zahir, E.; Asghar, M. A. On the practicability of a new bio sorbent: Lasani sawdust and coconut coir for cleanup of oil spilled on water, Petroleum Science and Technology, v. 37, p. 11431154, 2019.

https://doi.org/10.1080/10916466.2019.1578797

Deschamps, G.; Caruel, H.; Borredon, M. E.; Bonnin, C.; Vignoles, C. Oil removal from water by selective sorption on hydrophobic cotton fibres. 1 . Study of sorption properties and comparison with other cotton fibre-based sorbents. Environmental Science Technology, v. 37(5), p. 1013-1015, 2003. https://doi.org/10.1021/es020061s

Doshi, B.; Silanpää, M.; Kalliola, S. A review of bio-based materials for oil spill treatment. Water Research v. 135, p. 262-277, 2018.

https://doi.org/10.1016/i.watres.2018.02.034

Dotto, G. L.; Vieira, M. L. G.; Gonçalves, J. O.; Pinto, L. A. A. Remoção dos corantes azul brilhante, amarelo crepúsculo e amarelo tartrazina de soluções aquosas utilizando carvão ativado, terra ativada, terra diatomácea, quitina e quitosana: Estudos de equilíbrio e termodinâmica. Química Nova, v. 34(7), p. 1193-1199, 2011. https://doi.org/10.1590/S0100-40422011000700017

El-Din, G. A.; Amer, A. A.; Malsh, G.; Hussein, M. Review: Study on the use of banana peels for oil spill removal. Alexandria Engineering Journal, v.57, p. 2061-2068, 2018.

https://doi.org/10.1016/i.aej.2017.05.020

Elkady, M. F.; Hussien, M.; Abou-Rady, R. Equilibrium and kinetics behavior of oil spill process onto synthesized nanoactivated carbon, American Journal of Applied Chemistry, v.3, p. 22-30, 2015. https://doi.org/10.11648/j.ajac.s.2015030301.14

El-Sayed, R. E. Hassan and Fabrice Mutelet Use of Ionic Liquids for the Treatment of Biomass Materials and Biofuel Production. In Tech Open Science, Chapter 7, p. 132- 155, 2017. 
El Shahawy, A.; Heika, G. Organic pollutants removal from oily wastewater using clean technology economically, friendly biosorbent (Phragmites australis). Ecological Engineering v.122, p. 207-218, 2018.

https://doi.org/10.1016/i.ecoleng.2018.08.004

Foo, K.Y.; Hameed, B.H. Insights into the modeling of adsorption isotherm systems. Chemical Engineering Journal. v.156, p.2-10, 2010. https://doi.org/10.1016/i.cej.2009.09.013

George, A.; Brandt, A.; Tran, K.; Zahari, S. M. S. N. S.; Klein-Marcuschamer, D.; Sun, N. Design of low-cost ionic liquids for lignocellulosic biomass pretreatment. Green Chemistry, v. 17, p. $1728-$ 1734, 2015. https://doi.org/10.1039/C4GC01208A

Geron, L. J. V.; Cabral, L. S.; Machado, R. J. T.; Zeoula, L. M.; Oliveira, E. B.; Garcia, J.; Gonçalvez, M. R.; Aguiar, R. P. S. Evaluation of the content of neutral detergent fiber and acid through different procedures applied to forage plants. Ciências Agrárias, v. 35(3), p. 1533-1542, 2014.

https://doi.org/10.5433/1679-0359.2014v35n3p1533

Gorgulho, H. F.; Guilharduci, V. V. S.; Martelli, P. B. Sugarcane bagasse as potentially low-cost biosorbent. Intech Open, p. 265-280, 2018. https://doi.org/10.5772/intechopen.72153

Ho, Y. S.; Mckay, G. Pseudo-second order model for sorption processes. Process Biochemistry, v.34, p. 451-465, 1999. https://doi.org/10.1016/s00329592(98)00112-5

Hospodarova, V.; Singovszka, E.; Stevulova, N. Characterization of Cellulosic Fibers by FTIR Spectroscopy for Their Further Implementation to Building Materials. American Journal of Analytical Chemistry, v.9, p. 303-310, 2018.

https://doi.org/10.4236/ajac.2018.96023

Hou X-D.; Li N.; Zong M-H. Facile and simple pretreatment of sugar cane bagasse without size reduction using renewable ionic liquids-water mixtures. ACS Sustainaible Chemistry \& Engineering, v.1, p. 19-26, 2013. https://doi.org/10.1021/sc300172v

Hu, Y.; Zhang, Y.; Hu, Y.; Chu, C-Y.; Lin, J.; Gao, S.; Lin, D.; Lu, J.; Xiang, P.; Ko, T-H. Application of wasted oolong tea as a biosorbent for the adsorption of methylene blue. Journal of Chemistry, v. 2019, p. 1-10, 2019.

https://doi.org/10.1155/2019/4980965
Jesus, M.S.; Sousa, T.B.; Mori, F.A.; Guimarães, B.M.R. Fibras vegetais com potencial para reforço de compósitos poliméricos analisados a partir da Microscopia Eletrônica de Varredura - MEV. Revista O Papel, v. 76(8), p. $61-63$, 2015. (In Portuguese)

Kumar, G. S.; Natarajan, N. Effect of Sips Sorption Isotherm on Contaminant Transport Mechanism in Fractured Porous Media. Journal of Civil Engineering, v. 20(5), p. 1714-1720, 2016. https://doi.org/10.1007/s12205-015-1424-7

Liu, Y-R.; Thomsen, K.; Nie, Y.; Zhang, S-J.; Meyer, A. S. Predictive screening of ionic liquids for dissolving cellulose and experimental verification.

Green Chemistry, v. 23, p. 1-9, 2016.

https://doi.org/10.1039/C6GC01827K

Lopes, F. F. M.; Araújo, G. T.; Luna, S.; Nascimento, J. W. B.; Gadelha, T, S.; Silva, V. R. Estudo dos efeitos da acetilação em fibras de sisal. Revista Brasileira de Engenharia Agrícola e Ambiental, v. 14(7), p. 783-788, 2010a. (In Portuguese)

https://doi.org/10.1590/S1415-43662010000700015

Lopes, F. F. M.; Araújo, G. T.; Luna, S.; Nascimento, J. W. B.; Silva, V. R. Modificação das propriedades das fibras de curauá por acetilação. Revista Brasileira de Engenharia Agrícola e Ambiental, v. 15(3), p. 316-321, 2010b. (In Portuguese)

https://doi.org/10.1590/S1415-43662011000300014

MMA - MINISTÉRIO DO MEIO AMBIENTE. Espécies nativas da flora brasileira de valor econômico atual ou potencial. Brasília, 2011. Available at:

<http://www.mma.gov.br/clima/energia/fontesconvencionais-de-energia/petroleo>. Accessed on: 03 nov. 2018. (In Portuguese)

Miranda, C. S.; Fiuza, R. P.; Carvalho, R. F.; José, N. M. Efeito dos tratamentos superficiais nas propriedades do bagaço da fibra de piaçava Attalea funifera Martius. Quim. Nova, v. 38(2), p. 161-165, 2015. (In Portuguese)

Miranda, R. C. M.; Vilanova Neta, J.; Ferreira, L. F. R.; Gomes Júnior, W. A.; Nascimento, C. S.; Gomes, E. B.; Mattedi, S.; Soares, C.M.F; Lima, Á. S. Pineapple crown delignification using low-cost ionic liquid based on ethanolamine and organic acids. Carbohydrate Polymers, v. 206, p. 302-308, 2019. https://doi.org/10.1016/i.carbpol.2018.10.112 
Mohanty, A. K.; Misra, M.; Drzal, L. T. Surface modifications of natural fibers and performance of the resulting biocomposites. Composite Interfaces, v. 8, p. 313-343, 2001.

https://doi.org/10.1163/156855401753255422

Nethaji, S.; Sivasamy, A.; Mandal, A. B. Adsorption isotherms, kinetics and mechanism for the adsorption of cationic and anionic dyes onto carbonaceous particles prepared from Juglans regia shell biomass. International Journal of Environmental Science and Technology, v. 10, p. 231-242, 2013. https://doi.org/10.1007/s13762-012$\underline{0112-0}$

Nwadiogbu, J. O.; Ajiwe, V. I. E.; Okoye, P. A. C. Removal of crude oil from aqueous medium by sorption on hydrophobic corncobs: Equilibrium and kinetic studies. Journal of Taibah University for Science, v. 10, p. 56-63, 2016.

https://doi.org/10.1016/i.jtusci.2015.03.014

Oliveira, R. S.; Borges, M. F.; Vieira, A. T.; Henrique, M. A.; Ribeiro, E. A. M.; Bezerra, F. A.; Portela, F. M.; Pereira, N. R.; Assunção, R. M. N.; Ruggiero, R. Adsorção de contaminantes do biodiesel por fibras de bagaço modificadas na superfície. Química Nova, v. 41(2), p. 121-128, 2018. (In Portuguese) https://doi.org/10.21577/0100$\underline{4042.20170164}$

Onwuka, J. C.; Agbaji, E. B. Ajibola, V. O. Okibe, F. G. Kinetic studies of surface modification of lignocellulosic Delonix regia podsas sorbent for crude oil spill in water. Journal of Applied Research and Technology, v. 14, p. 415-424, 2016. https://doi.org/10.1016/i.jart.2016.09.004

Paula, R. G.; Boni, H. T.; Souza, A. A. U.; Yamamoto, C. I.; Takeshita, E. V. The sorption potential of sugarcane bagasse for oil spill contention and removal cases. Engevista, v. 19(1), p. 122-131, 2017.

https://doi.org/10.22409/engevista.v19i1.808

Perez-Pimienta, A.; Lopez-Ortega, M. G.; Chavez-Carvayar, J.Á.; Varanasi, P.; Stavila, V.; Cheng, G. Characterization of agave bagasse as a function of ionic liquid pretreatment. Biomass \& Bioenergy, v.75, p. 180-188, 2015.

https://doi.org/10.1016/j.biombioe.2015.02.026
Pimentel, P. M.; Oliveira, R. M. P. B.; Melo, D. M. A.; Melo, M. A. F.; Assunção, A. L. C.; Gonzales, $\mathrm{G}$. Adsorption of chromium ions on oil shale waste. Brazilian Journal of Petroleum and Gas, v. 5(2), p. 065-073, 2011.

https://doi.org/10.5419/bjpg2011-0008

Pin, T. C.; Nakasu, P. Y. S.; Mattedi, S.; Rabelo, S. C.; Costa, A. C. Screening of protic ionic liquids for sugarcane bagasse pretreatment. Fuel, v. 235, p. 1506-1514, 2019.

https://doi.org/10.1016/i.fuel.2018.08.122

Rabelo, S. C.; Carrere, H.; Maciel Filho, R.; Costa, A. C. Production of bioethanol, methane, and heat from sugarcane bagasse in a biorefinery concept. Bioresource Technology, v. 102, p. 7887-7895, 2011. https://doi.org/10.1016/i.biortech.2011.05.081

Ray D.; Sarkar B. K.; Rana A. K.; Bose N. R. The mechanical properties of vinylester resin matrix composites. Composites, Part A: Applied Science and Manufacturing, v.32, p. 119-127, 2001. https://doi.org/10.1016/S1359-835X(00)00101-9

Rocha, E. G. A.; Costa, A. C.; Aznar, M. Use of protic ionic liquids as biomass pretreatment for lignocellulosic ethanol production. Chemical Engineering Transactions, v. 37, p. 397-402, 2014.

Rocha, E. G. A.; Pin, T. C.; Rabelo, S. C.; Costa, A. C. Evaluation of the use of protic ionic liquids on biomass fractionation. Fuel, v.206, p. 145-54, 2017. https://doi.org/10.1016/j.fuel.2017.06.014

Santos, E. G.; Alsina, O. L. S.; Silva, F. L. H. Cinética de adsorção de poluentes orgânicos por bioadsorventes. Química Nova, v. 30, n. 2, p. 327331, 2007. (In Portuguese) https://doi.org/10.1590/S0100-40422007000200017

Segal, L.; Creely, J. J.; Martin JR., A. E.; Conrad, C. M. An empirical method for estimating the degree of crystallinity of native cellulose using $X$ ray diffreactometer. Textile Research Journal, $v$. 29, p. $786-794,1959$.

https://doi.org/10.1177/004051755902901003

Semerci, I.; Güler, F. Pretreatment of Crop Wastes from Edible Biomass with a Protic Ionic Liquid. International Journal of Renewable Energy Research, v. 9(1), 2019. 
Silva, F. L. B. M. Caracterização da fibra de cana-brava (Gynerium sagittatum) e sua viabilidade como reforço na preparação de compósitos com ABS. 112 f. Dissertação de Mestrado. Universidade Federal da Bahia - Escola Politécnica, 2017. (In Portuguese)

Silva, O. R.; Gomes, M. B. M. Impactos das atividades portuárias no sistema estuarino de Santos. Revista Metropolitana de Sustentabilidade, v. 2(2), p. 64-81, 2012. (In Portuguese)

Silva, R.; Haraguchi, S. K.; Muniz, E. C.; Rubira, A. F. Aplicações de fibras lignocelulósicas na química de polímeros e em compósitos. Química Nova, v. 32(3), p. 661-671, 2009.

https://doi.org/10.1590/S0100-40422009000300010

Sueiro, R. A.; Garrido, M. J.; Araujo, M. Mutagenic assessment of prestige fuel oil spilled on the shore and submitted to field trials of bioremediation. Sci. Total Environ, v.409, p. 49734978, 2011.

https://doi.org/10.1016/j.scitotenv.2011.08.017

Sun, X. F.; Sun, R. C.; Sum, J. X. Acetylation of sugarcane bagasse using NBS as a catalyst under mild reaction conditions for the production of oil sorption-active materials. Bioresource Technology, v. 95, p. 343-350, 2004.

https://doi.org/10.1016/j.biortech.2004.02.025

Szklo, A. Fundamentos de Refino de petróleo. Rio de Janeiro: Ed. Interciência, 2005.

Tamis, J. E.; Jongbloed, R. H.; Karman, C. C.; Koops, W.; Murk, A. J. Rational application of chemicals in response to oil spills may reduce environmental damage, Integrated Environmental Assessment and Management, v.8, p. 231-241, 2011.https://doi.org/10.1002/ieam. 273

Terzyk, A. P.; Chatłas, J.; Gauden, P. A.; Rychlicki, G.; Kowalczyk, P. Developing the solution analogue of the Toth adsorption isotherm equation. Journal of Colloid and Interface Science, v. 266(2), p. 473476, 2003.

https://doi.org/10.1016/50021-9797(03)00569-1

Trindade, M. E. J.; Mattedi, S.; Simonelli, G.; Santos, L. C. L. Use of protic ionic liquid ([DETA][Hx]) as co-solvent in biodiesel production. Brazilian Journal of Petroleum and Gas, v. 13(1), p. 057-065, 2019. https://doi.org/10.5419/bjpg2019$\underline{0006}$
Verdía, P.; Brandt, A.; Hallett, J. P.; Ray, M. J.; Welton, T. Fractionation of lignocellulosic biomass with the ionic liquid 1-butylimidazolium hydrogen sulfate. Green Chemistry, v.16, p. 1617, 2014. https://doi.org/10.1039/c3gc41742e

Vidal, R. R. L.; Moraes, J. S. Removal of organic pollutants from wastewater using chitosan; a literature review. International Journal of Environmental Science and Technology, v.16, p. 1741-1754, 2019. https://doi.org/10.1007/s13762$\underline{018-2061-8}$

Viju, S.; Thilagavathi, G.; Vignesh, B.; Brindha R. Oil sorption behavior of acetylated nettle fiber. The Journal of the Textile Institute, p. 1-8, 2019. https://doi.org/10.1080/00405000.2019.1603184

Wahi, R.; Chuah, L.A.; Choong, T. S. Y.; Ngaini, Z.; Nourouzi, M. M. Oil removal from aqueous state by natural fibrous sorbent: an overview, Separation and Purification Technology, v.113, p. 51-63, 2013.

https://doi.org/10.1016/i.seppur.2013.04.015

Wang, Z.; Barford, J. P.; Hui, C. W.; Mckay, G. Kinetic and equilibrium studies of hydrophilic and hydrophobic rice husk cellulosicfibers used as oil spill sorbents. Chemical Engineering Journal, v. 281, p. 961-969, 2015.

https://doi.org/10.1016/j.cej.2015.07.002

Wei, Q. F.; Mather, R. R.; Fotheringham, A. F.; Yang, R. D. Evaluation of Nonwoven polypropylene oil sorbents in marine oil-spill recovery. Marine Pollution Bulletin, v.46, p. 780-783, 2003. https://doi.org/10.1016/s0025-326X(03)00042-0

Xie, W.; Zhou, D.; Ren, Y.; Tang, S.; Kuang, M.; DU, S. 1-Butyl-3-methylimidazolium chloride pretreatment of cotton stalk and structure characterization. Renew Energy, v.125, p. 668-674, 2018. https://doi.org/10.1016/j.renene.2018.03.011

Yang, H.; Yan, R; Chen, H.; Zheng, C; Lee, D. H. Characteristics of Hemicellulose, Cellulose and Lignin. Energy \& Fuels, v. 80, p. 1781-1788, 2007. https://doi.org/10.1016/i.fuel.2006.12.013

Zhang, J.; Wang, Y.; Zhang, L.; Zhang, R.; Liu, G.; Cheng, G. Understanding changes in cellulose crystalline structure of lignocellulosic biomass during ionic liquid pretreatment by XRD. Bioresource Technology, v.151, p. 402-405, 2014. https://doi.org/10.1016/j.biortech.2013.10.009 